\title{
Cerámica ática documentada en el yacimiento de El Cerro de Alvar-Fañez (Huete, Cuenca): Cílica de figuras rojas. Grupo de Viena 116
}

\author{
Raquel Castelo Ruano \\ Universidad Autónoma de Madrid.
}

\begin{abstract}
Resumen
En este artículo presentamos el estudio de un fragmento de cerámica de figuras rojas documentada en el yacimiento de El Cerro de Alvar Fañez (Huete, Cuenca), yacimiento que fue excavado entre 1985 y 1987 bajo la dirección del Profesor M. Bendala Galán. El fragmento ha sido identificado como parte de una cilica del grupo de Viena 116 y su hallazgo contribuye a ampliar el conocimiento de importaciones griegas durante el siglo IV a.C, en el interior de la península.
\end{abstract}

Palabras clave: Vaso figuras rojas. Cilica. Oppidum Olcade

\section{Riassunto}

In questo articolo presentiamo lo studio di un fragmento di cerámica a figure rosse documentato nel giacimento de $\mathrm{El}$ Cerro de Alvar-Fañez (Huete, Cuenca), giacimento che fu scavato, fra il 1985 e il 1987 sotto la direzione del profesor M. Bendala Galán. II fragmento è stato identificato come parte di una "cilica" del Grupo di Viena 116 e il suo ritrovamento contribuisce ad ampliare il conoscimento sulle importazioni greche durante il IV secolo a.C. nell'interno della penisola.

Parole chiave: Vaso, Figure rosse, Cilica. Oppidum Olcade.

\section{EL CERRO DE ALVAR-FAÑEZ. UBICACIÓN.}

El yacimiento del Cerro de Alvar-Fañez se encuentra situado en una pequeña elevación de unos $960 \mathrm{~m}$. de altura configurada como un espolón amesetado, de mayor altura en su parte oeste y con laderas muy rápidas y escarpadas en sus vertientes norte, oeste y sur, lo que le confiere una posición estratégica sobre el valle situado entre el río Mayor y el río de La Aldehuela, pues lo domina visualmente. Este fuerte desnivel hace fácilmente defendible el lugar. El yacimiento se extiende entre las coordenadas $40^{\circ} 08^{\prime} 00^{\prime \prime}$ Norte y $1^{\circ} 01^{\prime} 00^{\prime \prime}$ según el Meridiano de Madrid. Se incluye en la Hoja 608 del mapa 1: 50.000 del Instituto Geográfico y Catastral. El paisaje circundante es de fértiles vegas, amesetado, con altitudes entre los 800 y los 1000 metros, del que sobresalen cerros originados por la profunda erosión y por los cauces fluviales. Por su alto contenido en yesos, éstos cerros son casi estériles. A su importancia visual hay que sumar la importancia histórica de la explotación de las minas de lapis specularis.

Se localiza a 1'5 km. al sudeste del actual municipio de Huete que pertenece a la Comarca 
de La Alcarria Conquense. Esta comarca se conforma como una submeseta surcada por diferentes sierras alineadas de norte a sur. La orientación de estas sierras y valles, así como el carácter abrupto y cambiante de su relieve han marcado profundamente el desarrollo de las comunicaciones y, por tanto, de los contactos de la zona, siendo casi nulos en sentido este-oeste, pero relativamente fáciles en sentido norte-sur. En consecuencia, la red viaria y el poblamiento humano de época antigua se asentaron a lo largo de estos valles (Figuras $n^{\circ}$ 1, 2, 3, 4 y 5).

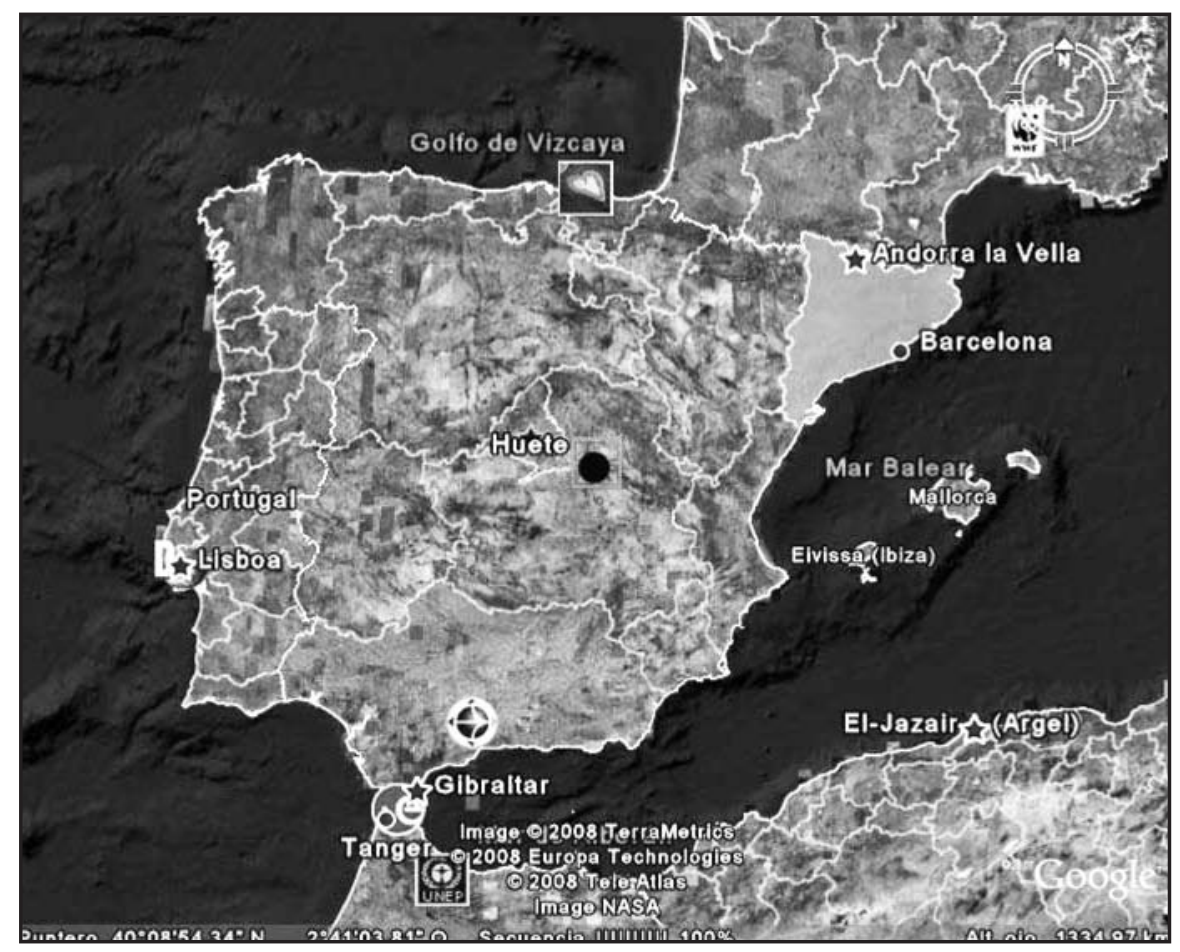

Figura $n^{\circ}$ 1.- Mapa de España con localización de Huete (Cuenca). Copyright Google Earth.

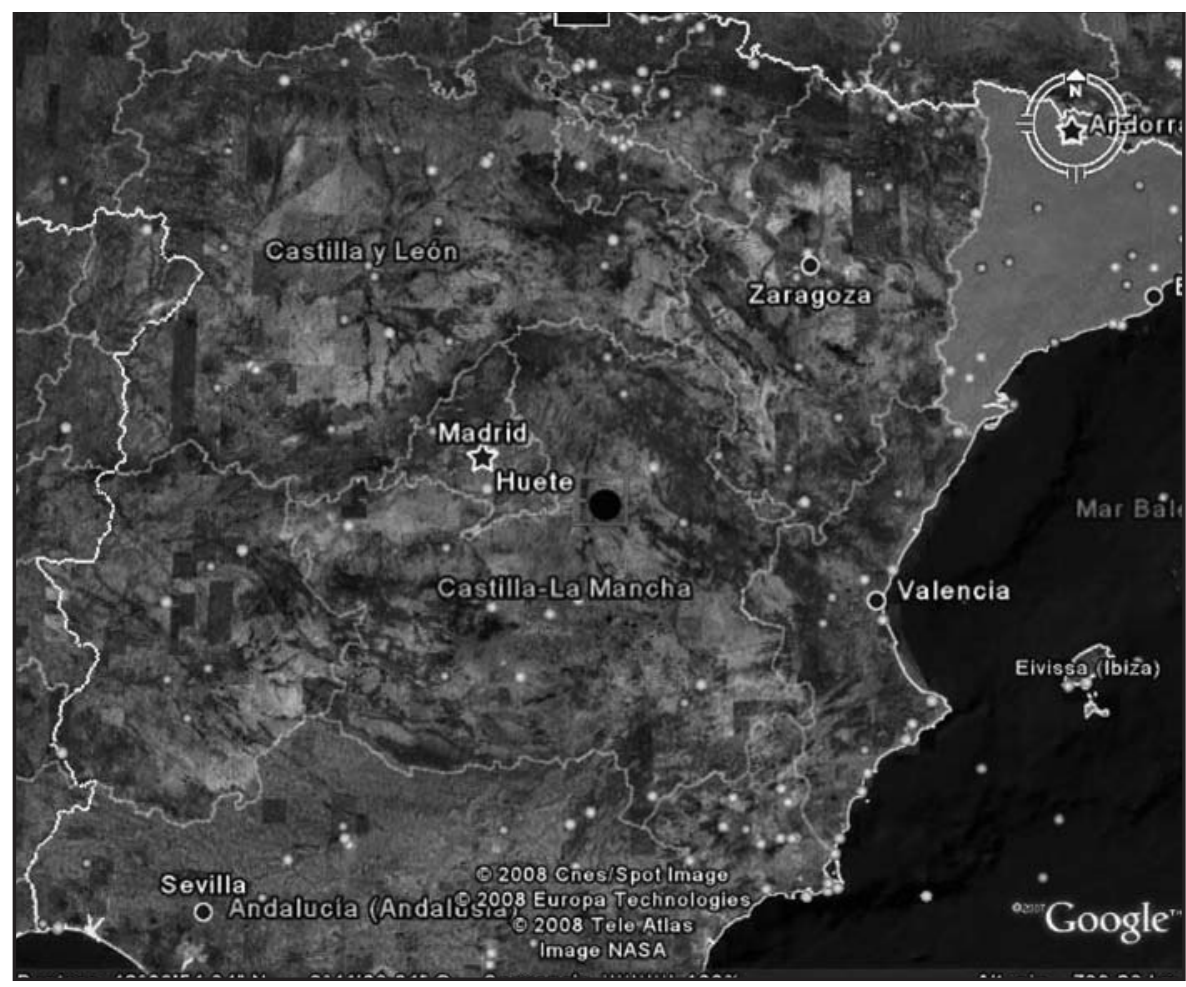

Figura $n^{\circ}$ 2.- Detalle del Mapa de España con localización de Huete (Cuenca). Copyright Google Earth. 


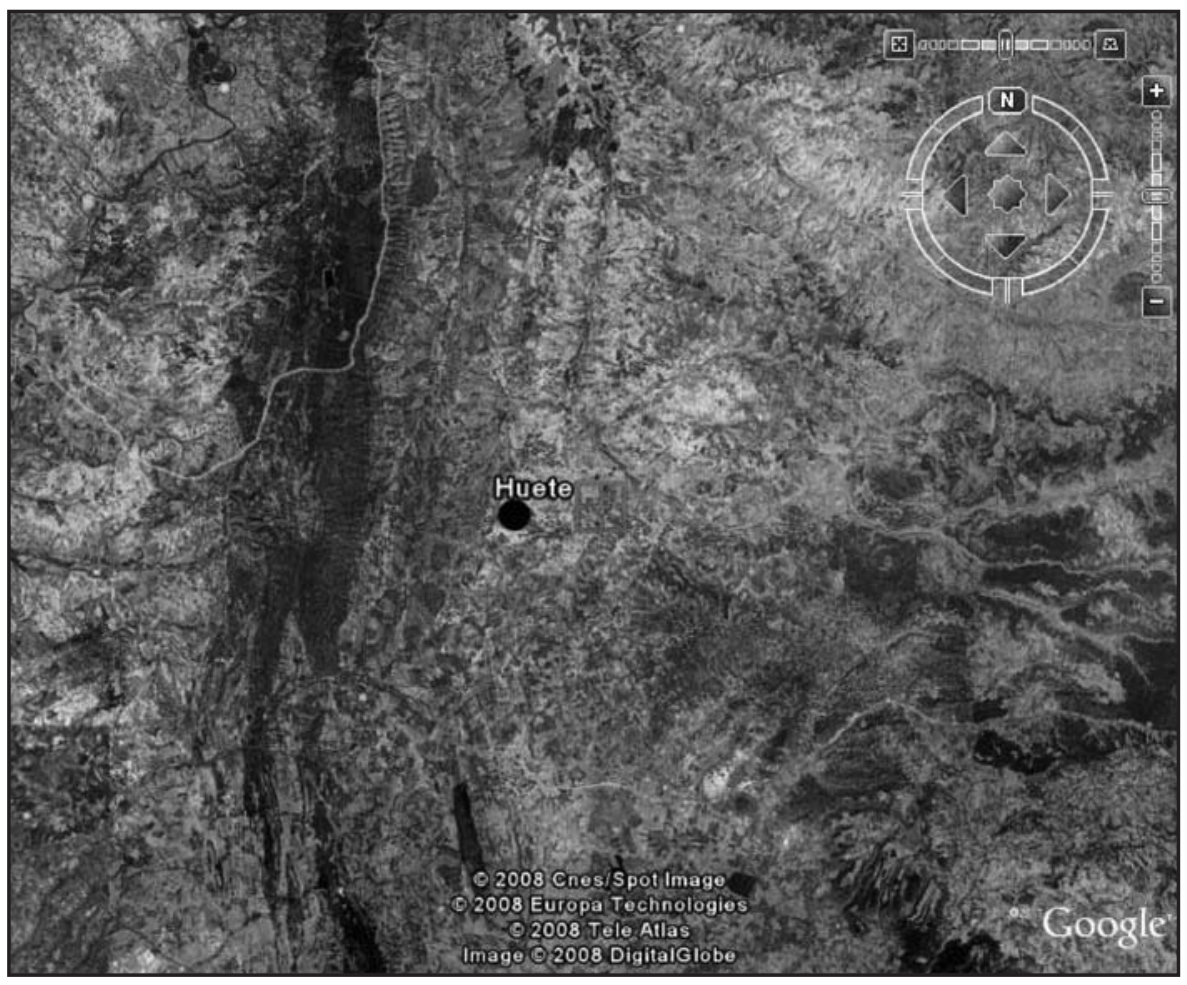

Figura $n^{o}$ 3.- Fotografía satélite. Se observa la orografía y la ubicación de Huete (Cuenca). Copyright Google Earth.

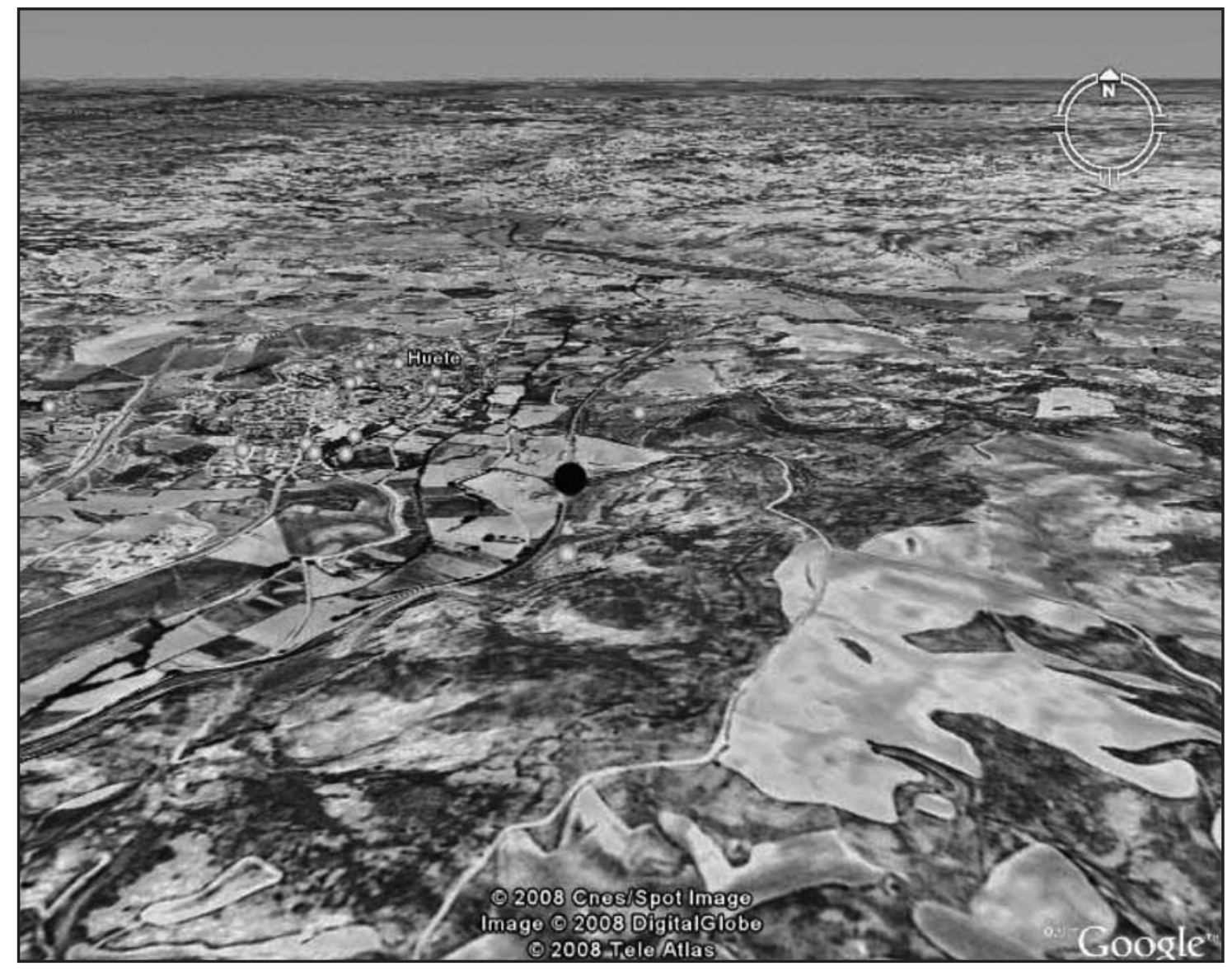

Figura $n^{\circ}$ 4.- Fotografía área con ubicación del Cerro de Alvar-Fañez (Huete, Cuenca). Copyright Google Earth. 


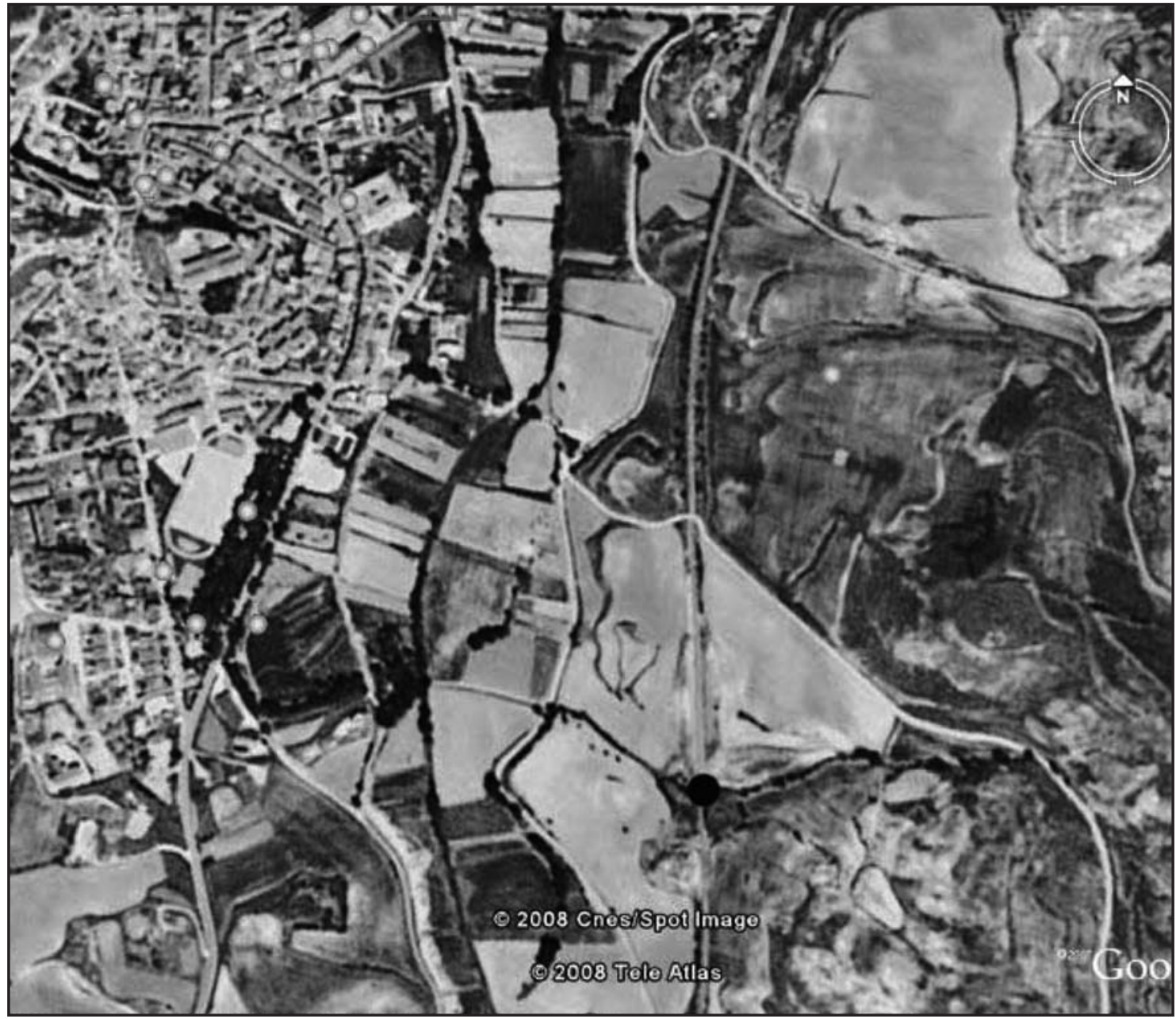

Figura $n^{\circ}$ 5.- Fotografía área con ubicación del Cerro de Alvar-Fañez (Huete, Cuenca). Copyright Google Earth

\section{LAS INTERVENCIONES ARQUEOLÓGICAS.-}

A través de la lectura de los expedientes conservados en el Gabinete de Antigüedades de la Real Academia de la Historia, podemos saber que los primeros hallazgos arqueológicos realizados en el Cerro de Alvar-Fañez se produjeron en 1856, cuando José de Corpa (vecino de Huete) labrando la tierra, enganchó el arado y arrancó un objeto (el asa de bronce de un pondus realizado en serpentina).

No se volverá a excavar en el yacimiento hasta 1879. En esa ocasión dirigieron los trabajos los señores José Caamaño y Paul Laporte, trabajos que fueron financiados por algunos vecinos de la ciudad de Huete.

Tendrán que pasar bastantes años para que se vuelva a prospectar y excavar el cerro. En esa ocasión los trabajos fueron dirigidos en los años 70 por Doña Aurora de Miguel quien contó con la colaboración de D. Ángel Fuentes Domínguez y D. Santiago Palomero.

En 1985 se hace cargo del yacimiento un equipo formado por miembros de la Universidad Autónoma de Madrid y la Universidad de Alicante. La excavación fue dirigida por D. Manuel Bendala Galán. Se abrieron, entonces los cortes A, B, C, D y F. Tras esta primera campaña se pudieron obtener una serie de resultados que fueron en un principio esperanzadores y del mayor interés. Se estableció, siempre con las cautelas propias de un enunciado muy provisional, lo siguiente: 1.- Entre las fases más recientes de la historia del yacimiento habían sido detectadas con nitidez las exploraciones arqueológicas del $\mathrm{s}$. XIX. Se trataba de zanjas irregulares que buscaron los muros para examinar los edificios allí levantados, de todo lo cual se tiene noticia en informes de la época remitidos a la Comisión Provincial de Monumentos de Cuenca y en publi- 
caciones inéditas que no hemos podido encontrar y por lo tanto consultar. 2.- La superficie posee testimonios muy escasos de una presencia medieval. 3.- A través de las cerámicas recuperadas se advirtió una fase de cierta vitalidad en el Bajo Imperio, fenómeno registrado en Valeria y otros yacimientos conquenses, hecho que parece ser confirmado por algunas monedas recogidas por D. Inocente González. A esta fase deben corresponder los muros de mala factura apoyados, algunos de ellos, en la obra romana más antigua. 4.La fase romana más importante corresponde a fines de la República y, sobre todo, a comienzos del Imperio. Entonces se debieron construir los grandes edificios que empezó a descubrir Aurora de Miguel, aunque ésta fase de gran actividad edilicia no parece durar mucho tiempo. 5.- Por último, destacaríamos la existencia de un importante nivel de ocupación celtibérica, un oppidum olcade (Figura $n^{\circ} 6$ ) que constituye uno de los aspectos más interesantes del yacimiento. Aunque poco analizado debido a la profundidad en que se encuentra y su cubrimiento por las importantes construcciones posteriores, se presenta como una fase de gran interés y riqueza, al menos en su contenido cerámico de tradición ibérica. Gracias a esta última circunstancia el yacimiento proporciona la posibilidad de estudiar en un mismo lugar los fenómenos de evolución, cambio y continuidad, que registran las sociedades protohistóricas en el periodo de romanización.

La segunda campaña de excavación se realizó en 1986. Se continuaron los trabajos en los cortes B, C y D, abiertos en la denominada zona A y se abrieron otros en la zona B (cortes BA, BB, BC y B) y en la zona C (corte CA).

La tercera campaña se realizó en septiembre de 1987 y durante ésta se continuó trabajando en la zona B (cortes BA, BB, BC y BD).

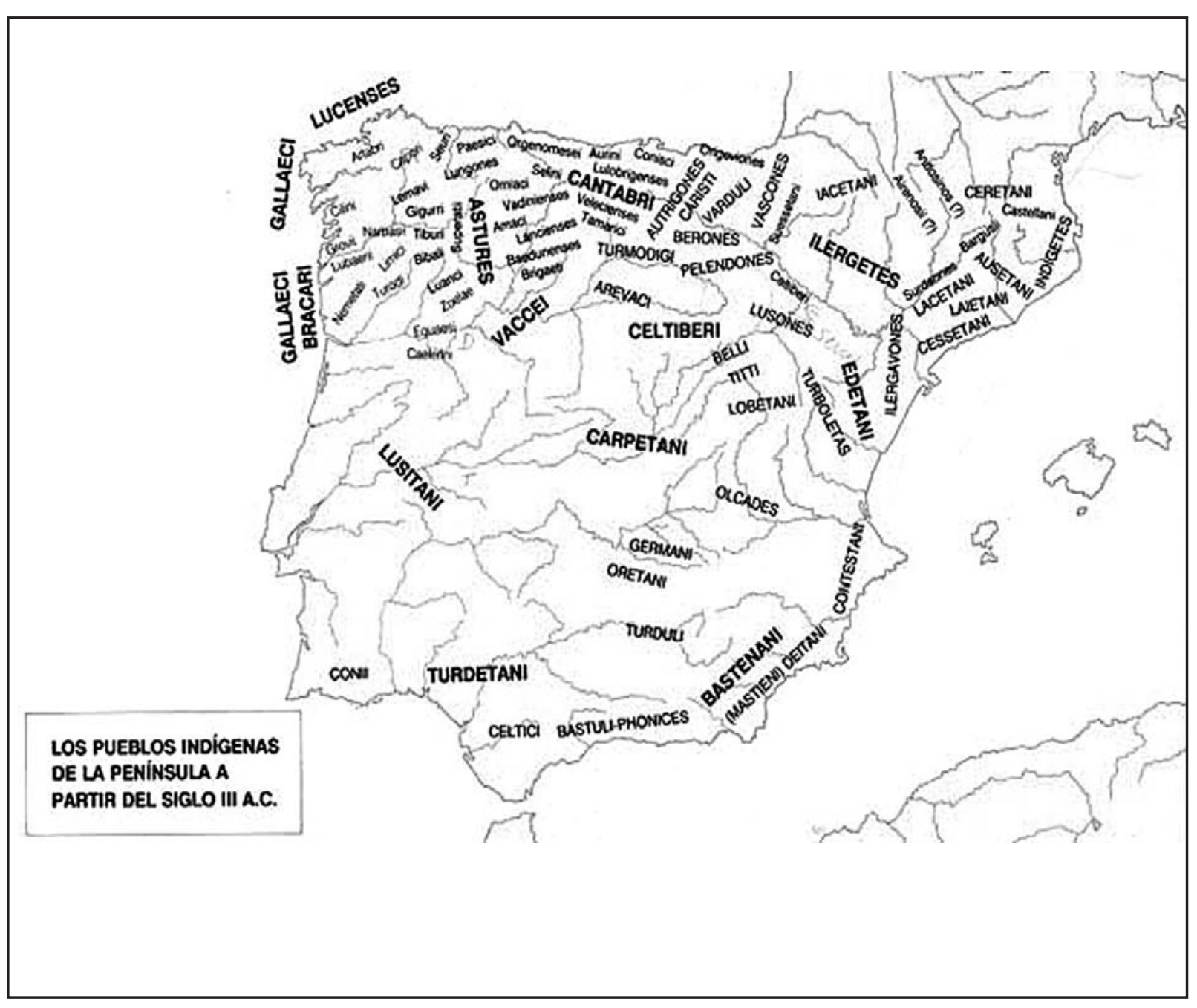

Figura $n^{o}$ 6.- Mapa de España con los pueblos prerromanos. Se indica la ubicación del pueblo olcade. 


\section{La cilica de Figuras rojas. Grupo VIENA 116}

En el yacimiento romano de Alvar Fáñez, tan sólo se ha documentado un pequeño fragmento de cerámica ática de figuras rojas procedente del Corte BA, nivel 3, sector x, abierto en la campaña de 1986.

La presencia de cerámica griega en los yacimientos ibéricos peninsulares constituye uno de los mejores y más seguros fósiles directores a la hora de establecer puntualizaciones cronológicas en torno a ellos y al mismo tiempo permiten trazar las vías de comunicación utilizadas para el comercio y el papel desempeñado por las diferentes áreas en este tránsito (García Huerta y Morales Hervás, 1999: 335).

Como bien señalan R. García Huerta y F. J. Morales Hervás, hasta fechas recientes la investigación sobre la incidencia del impacto mediterráneo, y más concretamente griego, sobre los pueblos prerromanos de la península ibérica se refería, fundamentalmente, a las zonas costeras con prolongaciones hacia el interior como en el caso de Albacete y Alta Andalucía. Sin embargo en los últimos años, las investigaciones arqueológicas han registrado la presencia de un gran número de elementos griegos en áreas del interior peninsular que ponen de manifiesto la existencia de importantes contactos de los pueblos colonizadores con éstas áreas que en muchos casos debieron de provocar una serie de cambios y transformaciones socioeconómicas (García Huerta y Morales Hervás, 1998, 335).

\section{IDENTIFICACIÓN Y DESCRIPCIÓN.}

La pieza fue examinada por el Dr. J. M. García Cano e identificada como el fragmento de una cilica de figuras rojas, perteneciente al Grupo de Viena 116, fechado en el segundo cuarto del siglo IV a.C. (Figura $n^{\circ} 7$ )

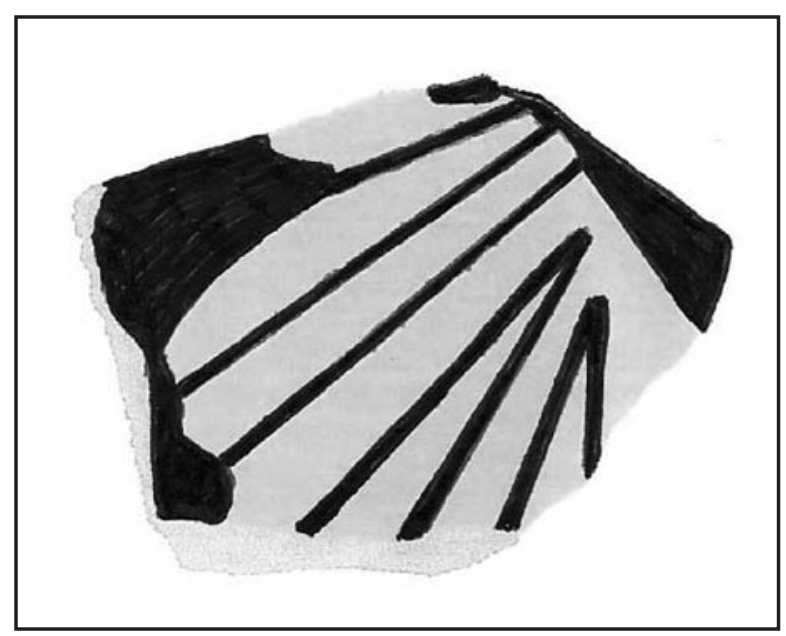

Figura $n^{\circ}$ 7.- Fragmento cilica figuras rojas Grupo de Viena 116 documentado en el Cerro de Alvar Fañez, (Huete, Cuenca), dibujo Castelo

La pieza corresponde a la parte exterior de un fragmento de pared, de pasta anaranjada. El interior está barnizado en negro brillante y en el exterior, la decoración conservada consiste en los pliegues de un himatión y parte del cabello de un joven que debió estar afrontado a otro personaje con la misma vestimenta y disposición. Piezas muy semejantes a la exhumada en el yacimiento de Alvar Fáñez son abundantes entre las importaciones áticas documentadas en los yacimientos ibéricos del sureste y Andalucía (García Cano, 1995: 127-131) (Figura no 8 y 9).

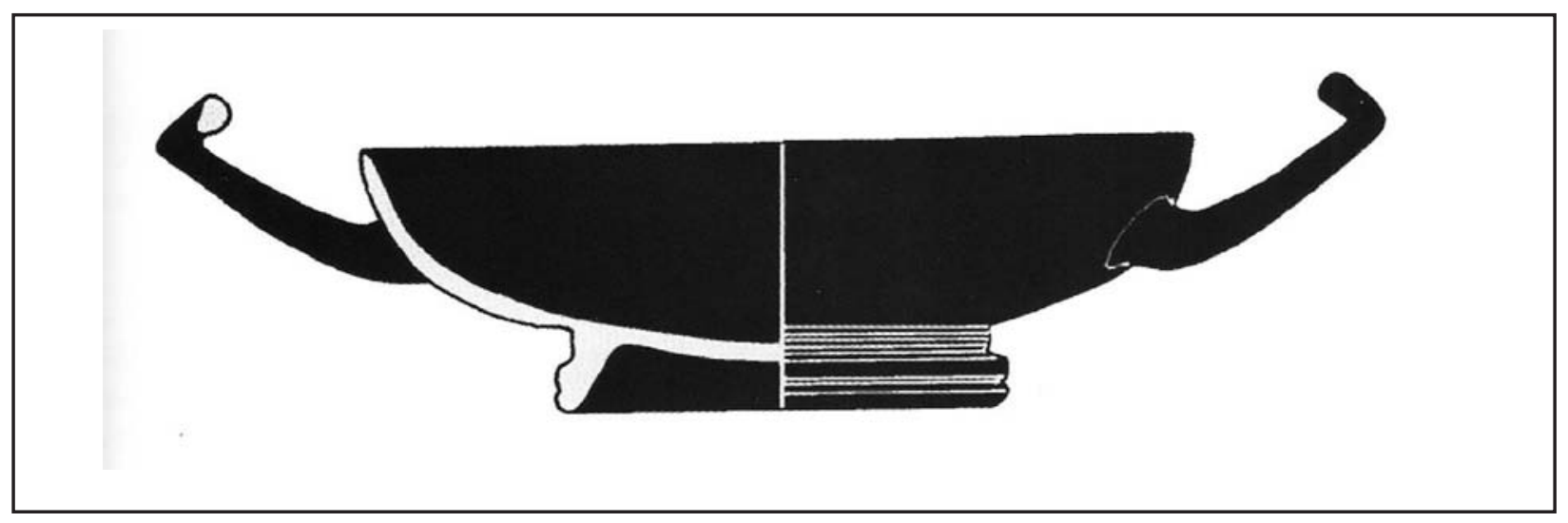

Figura $n^{\circ}$ 8.- Dibujo de una copa de pie bajo producida en un taller del Ática 


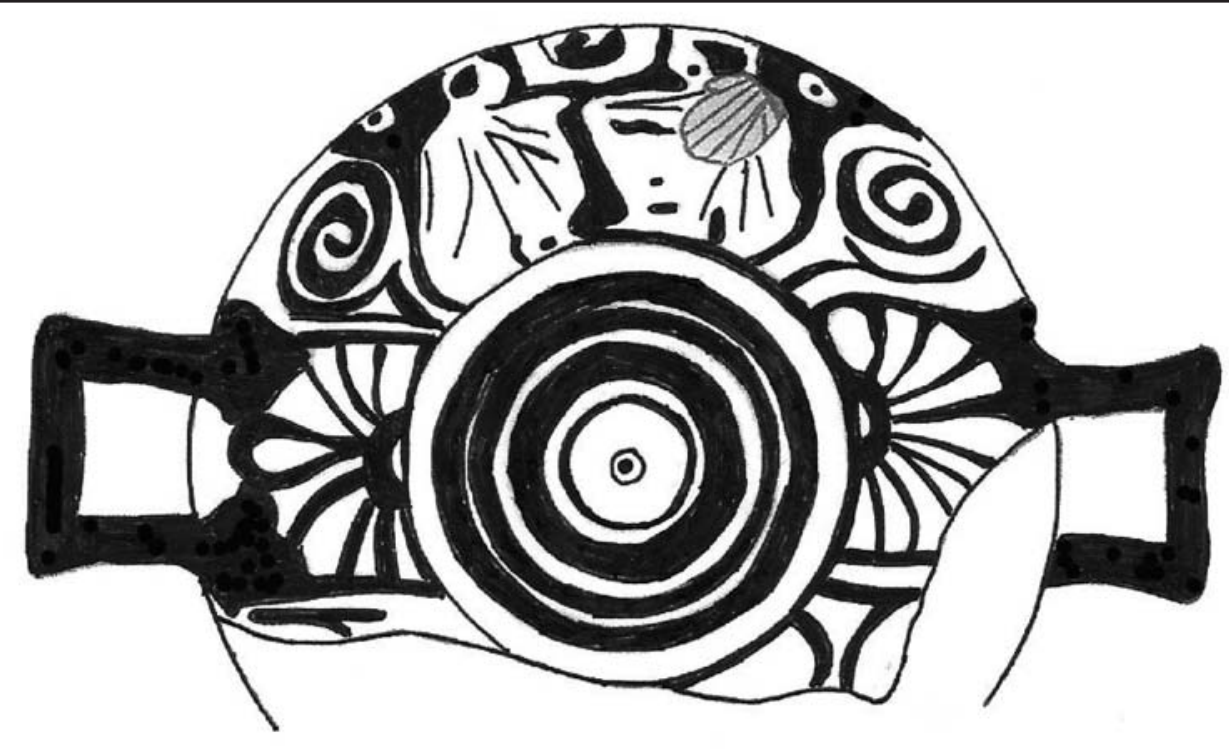

Figura $n^{\circ}$ 9.- Copa de pie bajo. Cilica documentada en el Pecio del Sec (Mallorca), se ha insertado el fragmento documentado en el Cerro de Alvar-Fañez, dibujo Castelo.

\section{Contexto del Hallazgo.}

El fragmento cerámico aquí estudiado fue documentado en la fase celtibérica del yacimiento excavado en el Cerro de Alvar-Fañez. Nos inclinamos a pensar que pudo tratarse de la Istonium citada por las fuentes literarias, concretamente por Tolomeo en sus Graduaciones o Tablas Geográficas. Esta identificación fue realizada ya en 1836 por Miguel Cortés y López en su Diccionario Geográfico de la España Antigua Tarraconense, Betica, donde se dice que Istonium significa hito, arrojamiento o señal divisoria, Alvar-Fañez, una división natural entre las vegas del Río Mayor y Aldehuela. En relación a Istonium, Miguel Cortés recoge lo siguiente: "sabemos de positivo acerca de esta ciudad que estaba en la celtiberia rigurosa, y que era de las más occidentales de esta región, tocando ya con la Carpetania. Comparada su latitud con la de Valeria, estaba Istonium 25 minutos más alta de poco que aquella, y un grado de 15 leguas de Tolomeo al occidente de esta ciudad. Esto es lo único que geograficamente podemos decir de esta ciudad no mencionada por otro..” “... El fabuloso P. Higuera soñó que había estado en Villavieja, despoblado cercano a Hito..",... Según Córnide en su memoria, tom.3 de las de la Academia, mudó de pensar Higuera, y creyó hallar Istonium enterrada en La Redonda, o en Los Fosos de Bayona. Antes u otra vez la redujo a Cañavate, y esto le pareció mejor al citado Cornide. Jacome Capistrano de Moya opinó primero que Istonium había estado en Villavieja, despoblado junto al río Xiguela. Más pasados algunos años, cuando el P. Risco dijo que era evidente el sitio de Certima en Alconchel, y que Munda estaba distante de Certoma XX millas, fundando su demostración en dos inscripciones, calificadas ya mucho antes de apócrifas por D. Gregorio Mayans, Capistrano arrancó de Villasviejas a su Istonium y colocó allí Munda. Si se hubiera de juzgar solamente por alguna, aunque remota, analogía, parecía verosimil que Istonium hubiera estado en Hito, y así han opinado algunos; pero Hito ni está a la latitud que Tolomeo dio a Istonium, estando en el mismo paralelo que Valeria, y no 25 minutos o 6 leguas, como lo estaba Istonium; ni hay necesidad de buscar la remota semejanza de Hito, teniendole idéntica, evidente y elevada en la ciudad de Huete. Esta es sin disputa la antigua Istonium; todos la tenían delante de los ojos y nadie hacia alto de ellas, de su antigüedad, de su latitud al norte de Valeria, de su longitud arrimada ya a la Carpetania, y sobre todo de su nombre. La falta de observación sobre las alteraciones que causan con los nombres las pronunciaciones o dialectos, ha sido la causa de que ningún escritor haya fijado a Istonium en Huete. Pronunciado Istonium a lo eólico, muy usado modo de pronunciar en los latinos se convirtió en Vistonium o Histonium; luego en Vette y Huedde o Vedde, así era llamada en tiempo de los árabes; y ultimamente en Huete...”.... Ruy Vamba opinó que Istonium estuvo en Cabeza de Griego, sin que este escritor, 
ni a Risco, ni a Masden hayan hecho fuerza los argumentos con que se ha querido probar haber estado alli la antigua Segobriga”.

El yacimiento de Istonium no solo presenta una posición estratégica sobre el valle conformado entre el río Mayor y el río Aldehuela, sino que tuvo una excelente visibilidad sobre los terrenos adyacentes, circunstancia que explica, en gran medida, el hecho de que se trate de un enclave con continuidad poblacional desde el Hierro II a época romana. Sigue el mismo patrón de asentamiento que el resto de oppida olcades fechados en el siglo IV a.C. (Althea, Cartala, Segobriga, Caesada, Valeria o Ercávica) situados en las altiplanices del occidente de Cuenca, con preferencia por cerros destacados en las amplias llanadas aptas para la agricultura de secano (Jimeno et alii 2005, 36).

De esta primera fase de ocupación celtibérica no hemos constatado estructuras arquitectónicas, aunque si contamos con abundantes elementos de cultura material. En este sentido, debemos incluir en este contexto, el fragmento de figuras rojas aquí estudiado, cerámicas de barniz negro (IV d.C.), cerámica pintada ibérica, monedas acuñadas en las cecas ibéricas de Arse (Sagunto); Bilbilis (Calatayud), Titiakos (Tricio) y Sekaisa (Belmonte de Gracián), con cronologías que no van más allá de 133 a.C., así como fíbulas anulares hispánicas. Todo ello evidencia la ocupación del espacio del yacimiento por parte de una comunidad que establecía contactos comerciales y relaciones culturales con diferentes ámbitos (Atlántico y Mediterráneo) en los momentos previos y durante la fase de la conquista romana.

Las siguientes fases de ocupación corresponden a época republicana y comienzos del imperio, momento en que el yacimiento alcanza su mayor importancia, importancia que pudo venir determinada por la explotación de las minas de lapis specularis, actividad que se gestionó como una minería de interior. Su explotación modeló el paisaje y dinamizó la región. Las elites locales y las ciudades cercanas, entre ellas Istonium u Opta, fueron las más beneficiadas (Bernardez Gómez y Guisado di Monti, 2004, 253). La ciudad de Istonium primero y Opta después pudo haber funcionado como un centro gestor de la explotación del lapis, explotación que estaría bajo el control de Segobriga. Esta ciudad fue el epicentro geográfico del conjunto minero extendido por las zonas de Sierra, Alcarria y Mancha de la provin- cia de Cuenca (Guisado di Monti y Bernández Gómez, 2002, 277-278). La última fase de cierta vitalidad en el yacimiento corresponde con el Bajo Imperio. El declive constatado a partir de esta época podría explicarse por el uso del vidrio soplado que se impuso finalmente sobre el empleo del lapis specularis para la construcción de ventanales. Esta nueva moda trajo consigo el abandono de las minas de yeso ubicadas en su entorno y esta circunstancia acabó con la razón de existir de la Opta romana (Castelo et alii, 2004,118).

La secuencia del poblamiento constatada en Alvar- Fañez reviste un gran interés, ya que a través de ella es posible estudiar los fenómenos de evolución, cambio y continuidad que registran las sociedades protohistóricas en el proceso de romanización. En definitiva, la ciudad primero celtibérica y después romana de Istonium u Opta se presenta, a tenor de los estudios arqueológicos, como uno de los yacimientos más especialmente significativos, en relación con las grandes ciudades romanas de Segobriga, Ercavica y Valeria, jugando un papel de centro económico relevante en las fases republicana y altoimperial. En segundo lugar porque se muestra como un espacio de evolución cultural en el que queda de manifiesto los importantes procesos de aculturación a que se vieron sometidos los habitantes de la meseta con la llegada de los conquistadores romanos.

\section{LA CERÁMICA GRIEGA EN LA PROVINCIA DE Cuenca.}

La cerámica griega documentada en la provincia de Cuenca es conocida a través de un estudio de síntesis realizado por M. J. Patiño, estudio que fue presentado en el Primer Congreso de Historia de Castilla-La Mancha. En él se recogen los yacimientos de la actual provincia de Cuenca que presentan hallazgos de cerámica griega, ya sea de figuras rojas o de barniz negro.

Los yacimientos que cita son los siguientes: Segóbriga (Saelices): fragmentos de vasos, cilicas, ánforas, etc., de figuras rojas, fechadas entre los ss. V y IV a.C.; así como cerámica de barniz negro del siglo IV a.C.; Necrópolis de Las Madrigueras (Carrascosa del Campo): en este yacimiento apareció una sola pieza ática, una cilica de pie bajo que se recortó para ser reutilizada; la pieza se fecha a fines del siglo V-comienzos del siglo IV a.C.; Reillo: cuenta con cerámica griega 
de barniz negro con decoración de palmetas en el interior, encontrada en superficie y fechada en el siglo V a.C.; Cerro de la Muela (Valera de Abajo): yacimiento que presenta una escasa proporción de cerámica griega; Necrópolis de El Navazo (La Hinojosa): se documentó una tapadera de lecane de figuras rojas con la escena del rapto nupcial y ovas completando la decoración, el pie y fondo de un vaso de barniz negro, fragmento de cratera de figuras rojas con decoración de hojas de laurel, piezas fechadas entre fines del siglo $\mathrm{V}$ principios del siglo IV a.C.; Buenache de Alarcón: donde se ha documentado un solo fragmento y Olmilla de Alarcón: con la presencia de asa de cratera de campana de figuras rojas y el fondo de una pátera con palmetas, fragmentos fechados en el siglo IV a.C.

Como conclusiones estableció los siguientes puntos: 1.- El mayor porcentaje de cerámica griega aparecida en la provincia de Cuenca corresponde a finales del siglo $\mathrm{V}$-comienzos del siglo IV, época de apogeo del mundo ibérico. 2.- Los yacimientos en los que se constatan están situados en zonas de fácil acceso y buena comunicación en cerros y promontorios desde donde se dominan amplios valles y en su mayoría forman parte de los ajuares de las tumbas. 3.- Muchos de estos yacimientos perviven en el tiempo y permiten apreciar que la cerámica griega ha sido objeto de frecuentes reutilizaciones. 4.- Llegan a esta zona a través del sur y sureste peninsular.

Para explicar la presencia de la cerámica griega en la actual provincia de Cuenca, podemos emplear las reflexiones realizadas por García Huerta y Morales Hervás para la presencia de importaciones áticas en la Meseta Suroocidental. Para éstos investigadores, hay que hacer una distinción entre el origen primario y el secundario de las piezas. El origen primario se encontraría en el Ática, desde donde serían transportadas hacia el Mediterráneo occidental, bien por comerciantes foceos o por intermediarios púnicos. El origen secundario corresponde a los enclaves de la costa peninsular desde los cuales las importaciones se llevaron hacia el interior. Para referirse a estos enclaves comeciales se viene acuñando el término de puerto de comercio, situados a orillas del mar o de un río. Los navegantes mediterráneos contarían en éstos lugares con agentes que organizarían previamente los contactos y el tráfico mercantil entre sus clientes y los receptores indígenas. Ampurias, Cádiz y Huelva debieron de repre- sentar este papel pero no serían los únicos puntos de contacto, habría, pues, otros puertos de comercio: desembocadura del Vinalopó o Cástulo tal y como sugiere Domínguez Monedero.

Desde los distintos puertos de comercio serían los núcleos indígenas los encargados de introducir los productos e influencias mediterráneas hacia el interior a través de sus propias redes comerciales. Por último, al igual que ocurre en otras regiones del interior de la península, "la presencia de cerámica griega en la provincia de Cuenca es un claro exponente del alcance que, a partir de éstos impulsos comerciales, llegaron a modificar sus estructuras económicas, sociales y demográficas" (García Huerta y Morales Hervás, 1999: 340-343).

\section{LA CERÁMICA ÁTICA DE FIGURAS ROJAS DEL SIGLO IV Y LAS CILICAS DEL GRUPO DEL Pintor de Viena 116}

La producción de vasos de figuras rojas ocupó un lugar destacado en la historia económica, comercial, artística e ideológica de la Atenas del siglo V a.C. Esta producción tras la derrota de la ciudad en las Guerras del Peloponeso sufrió una transformación importante y decisiva. Los autores, encargados de su análisis, como P. Cabrera o P. Rouillard han llegado a la conclusión de la existencia de un declive gradual, lento e imparable, no solo del nivel de fabricación sino también de la calidad de los pintores que decoran los vasos del siglo IV, reducción del repertorio de formas decoradas; una menor presencia de personalidades artísticas; sus estilos son difíciles de definir y de distinguir y las producciones reciben los adjetivos de "confusos, poco innovadores, mediocres o descuidados" (Cabrera y Rouillard, 2004: 91).

El máximo desarrollo del comercio griego en Iberia coincide con la consolidación de la cultura ibérica. En el siglo V a.C. el mundo ibérico, especialmente en la zona oriental de la Península, se convierte en un nuevo y floreciente mercado que atrae a los comerciantes mediterráneos (púnicos y griegos). Es el momento en el que llegan masivamente a la península importaciones de vasos áticos, bronces, vino y aceites griegos. Las sociedades ibéricas, con estructuras sociales cada vez más complejas, participan de éstas actividades de intercambio que les permitían dar salida a sus excedentes productivos y les proporcionaban objetos de lujo. 
Las poblaciones ibéricas no quedaron al márgen de la comercialización y éxito de las producciones áticas; se convirtieron en grandes consumidoras de estas vajillas, por lo general barnizadas de negro aunque también de figuras rojas sobre todo entre los años 425 y 350/325 a.C. Durante esta centuria, hasta el poblado más pequeño de la geografía ibérica recibe importaciones de cerámicas atenienses (30 Años de investigaciones en Coimbra del Barranco Ancho, Jumilla).

La existencia de este mercado mediterráneo supuso, para el mundo ibérico, la consolidación de las aristocracias locales cuyo poder y prestigio estaban basados también en su habilidad para controlar el aprovisionamiento y redistribución interna de los productos de lujo mediterráneos. Con frecuencia, la cerámica ática en general, fue un producto destinado a su amortización suntuaria en la tumba como elemento de prestigio necesario para la reproducción de un sistema social jerarquizado y ligado al consumo ostentoso de las élites aristocráticas y sus clientes (Cabrera, 1994: 89-101).

En Andalucía, las importaciones griegas para el primer cuarto del siglo IV a.C. son escasas y las que se han documentado pertenecen al área de la Alta Andalucía; sin embargo a partir del 380 a.C. se produce un salto espectacular, tanto en el repertorio tipológico como en el número de vasos que llegan a Andalucía. Será entre el 380 y el 350 cuando se registre el máximo volumen de importaciones, al igual que en otras zonas de la península. Los pintores más representados son el del Tirso Negro, el Pintor de Toya y el denominado como Retorted Painter. En cuanto a las formas, se constatan cráteras, copas del círculo de Viena 116 asociadas a escifos del grupo Fat Boy - considerados por diversos autores como productos de un mismo taller, tal y como se puede deducir del Pecio del Sec (Calviá, Mallorca). A partir del 350 a.C. las importaciones griegas se reducen pero no desaparecen como se había propuesto anteriormente. A partir del 340 desaparecen las importaciones de figuras rojas y se documentan piezas de barniz negro con un repertorio tipológico muy reducido y será a partir de los últimos años del siglo IV cuando éstas se interrumpan totalmente. Cabrera Bonet propone que la ciudad de Ampurias (Gerona) canalizó el intercambio de productos griegos con la región andaluza, a través de Villaricos y Cádiz. La ciudad ampuritana, sería, por tanto, un centro agluti- nador de productos áticos y desde allí serían difundidos por comerciantes de diversos enclaves indígenas o púnicos, sin olvidar la Isla de Ibiza (Cabrera, 1997: 369-390). La investigadora C. Sánchez estudió las importaciones griegas en Andalucía oriental, llegando a la conclusión de que los productos áticos que llegaban a esta región, y en general a Andalucía lo hacían en lotes y eran producidos en un gran taller que trabajó alrededor del segundo cuarto del s. IV a.C. y que dedicó gran parte de su producción a la exportación. En él trabajaron los pintores del grupo de Telos, de los que el más prolífico y el que más veces se ha constatado en la Península Ibérica es el Pintor del Tirso Negro que adapta su producción - seleccionando imágenes y tamañosa la demanda de los iberos del sur y del sureste peninsular. En el citado taller ateniense llegaron a producirse cráteras de campana, copas del grupo de Viena 116 e incluso vasos de barniz negro, páteras y pequeños cuencos o saleros (Sánchez, 1994: 210).

En la región del sureste peninsular, el impacto del comercio griego se manifiesta de una manera más bien tardía. Tan sólo se cuenta con un fragmento de copa perteneciente al siglo VI a.C. procedente de Cabezo de Tío Pío (Archena) y unos cuantos fragmentos de cerámica procedentes de yacimientos alicantinos (Tossal de Manises, Cabezo Lucero y Sierra del Molar). A este momento cronológico pertenecen también dos piezas de bronce: el centauro de Rollos y el sátiro itifálico del Llano de la Consolación, piezas, todas ellas, que corresponden a la primera etapa de los contactos comerciales entre las poblaciones indígenas del sureste y los pueblos colonizadores. Estos escasos contactos comerciales continuarán hasta el final del siglo VI a.C. tal y como se aprecia en determinados puntos: Los Nietos, Llano de la Consolación y Bastida de les Alcuses y el Molar. Será en las últimas décadas del siglo $\mathrm{V}$ a.C. y sobre todo durante la segunda mitad del siglo IV a.C. cuando se desarrolla el apogeo del comercio griego con el sureste, es el momento en que prácticamente todos los poblados ibéricos reciben vajilla ática, desde los más ricos hasta los más inhóspitos. En éste periodo, los vasos se pueden adquirir con mayor facilidad en relación a periodos anteriores, aunque seguían siendo considerados como vajilla de lujo. Entre fines del siglo V a.C. y principios del siglo IV a.C. (430390/385) predominan los cantaros de la clase Saint Valentin, las cilicas de pie bajo de barniz 
negro y los escifos; en la primera mitad del siglo IV (380-350 a.C.) se documentan cráteras de campana, la mayoría del pintor del Tirso Negro y cilicas de pie bajo, el tipo más abundante en el sureste, al igual que en otros puntos de la península, tal y como hemos visto (García Cano, 1987, 59, 60 y ss.). García Cano y Page del Pozo señalan, que la uniformidad de los tipos se debe a una selección temática que se realizaría en Atenas, eligiéndose los temas según los gustos que imperaran en cada momento. Para explicar su presencia en el sureste, se ha sugerido - al igual que en Andalucía- que las cerámicas áticas llegan a través de Ampurias y su esfera de influencia, desde aquí el material se redistribuía por los poblados indígenas del levante y sureste, a través de la desembocadura del Segura, llegando también a las zonas mineras de la Alta Andalucía. No se descarta que las Baleares distribuyeran también éstas cerámicas, tal y como se deduce de los hallazgos realizados en el pecio del Sec, donde hay cerámicas prácticamente idénticas a las documentadas en el yacimiento de El Cigarralejo (Mula, Murcia) (García Cano y Page del Pozo, 1987: 68 y ss.).

En resúmen, en el siglo IV a.C. llega a los yacimientos ibéricos gran cantidad de cerámica importada, decenas, centenares de vasos o fragmentos se han encontrado en cada necrópolis y poblados ibéricos de este momento cronológico. En el poblado de Ullastret (Gerona), en todas las casas hay un ajuar de cerámica ática en ésta época. Una gran parte de estas importaciones cerámicas que llegan a la franja mediterránea, desde Andalucía hasta Ampurias, son vasos relacionados con el consumo del vino y la bebida: cráteras de forma acampanada y copas con decoraciones figuras, profundos escifos de asas horizontales, en barniz negro o decoraciones figuradas, copas-escifo, bolsales, etc. Vasos todos ellos fabricados en talleres del Barrio ateniense del Cerámico y realizados a partir del siglo IV a.C. para su exportación, para su venta en lejanas regiones periféricas, decorados con temas y figuras que pudieran agradar, como ya hemos señalado, a sus remotos compradores. Los talleres áticos del siglo IV, más grandes, llegaron a reunir mano de obra cualificada junto a aprendices. En el siglo IV los artístas ya no compiten entre sí como en el siglo anterior por la belleza y calidad de sus productos. La pérdida de este espíritu competitivo, característico de la producción cerámica ática, al menos desde el siglo VI a.C. conlleva una despreocupación por la calidad del vaso, una fabricación rápida, barata y donde la única competitividad -si existe alguna- es cuantitativa. El exigente mercado italiano, que en el siglo IV cuenta con sus propias producciones cerámicas, se sustituye por el de las regiones periféricas como la Póntica o la del lejano occidente, donde sus habitantes menos helenizados son capaces de aceptar estos productos de mala calidad e incluso, a veces defectuosos. El cuidadoso esquema preliminar del siglo $\mathrm{V}$ realizado a base de líneas con punzón romo o un carbón en el que se encajaba meticulosamente la escena, se reducirá a unos rápidos trazos que esbozan el contorno de algunos fragmentos. Se ha planteado la posibilidad de que varios pintores decoraran el mismo vaso (Sánchez, 1992: 23-33 y 1996: 76).

Estos vasos recorrían un largo viaje marítimo, cuidadosamente apilados entre viruta en los barcos, hasta llegar a las costas españolas (Olmos y Sánchez, 1995: 123). Este medio de transporte se puede observar en el pecio del Sec (Calviá, Mallorca), un barco hundido a mediados del siglo IV a.C. y situado a las afueras de la bahía de Palma. Este hallazgo permitió conocer a sus investigadores la variedad de objetos que formaban parte de las importaciones de ésta época. El barco se dirigía hacia la península ibérica cargado de productos griegos destinados a las poblaciones ibéricas de la costa del levante e interior de Andalucía. El análisis del cargamento es un documento de primer orden, tal y como señalan Cabrera y Rouillard, para conocer los tráficos de mercancías, la nacionalidad de los comerciantes, las rutas comerciales y de navegación. La carga principal era el vino y asociado a él viajaban vasos áticos de figuras rojas y barniz negro. Las ánforas con vino eran de diversas procedencias (Corinto, Cos, Rodas, Quios, Tasos, Mar Negro y Mediterráneo central); sítulas; lebetas; vasos de bronce centromediterráneos; vasos áticos muchos de ellos con grafitos comerciales en griego o en púnico; copas del grupo de Viena 116; cráteras de campana y vasos de barniz negro (páteras, bolsales, cuencos, etc.), que bien pudieron ser productos de un único gran taller ateniense; las cráteras halladas de pequeño tamaño fueron decoradas por un único pintor: el del Tirso Negro, un artista que exportaba gran parte de su producción hacia regiones periféricas y en gran medida a la región del Mar Negro y a la Península Ibérica (Cabrera y Sánchez, 2000: 138). Se ha llegado a la conclusión de que el barco hundido en la bahía 
de Palma de Mallorca fue un barco púnico que había navegado hasta Samos donde adquirió la mayor parte del cargamento anfórico. Posteriormente haría escala en el puerto de El Pireo, donde cargó los vasos áticos, las ánforas de Corinto, de Mende, Sínope, Tasos y Cos, para dirigirse al Mediterráneo central, posiblemente Sicilia o algún centro importante de la Magna Grecia donde obtuvo un elevado número de ánforas vinarias de producción local y algunos objetos de bronce de gran valor. Pudo haber hecho escala, también, en Cartago y en Ibiza (Cabrera y Rouillard, 2004: 129).

La frecuencia de tipos varía de unas regiones a otras. En los yacimientos ibéricos de la Alta Andalucía son más numerosas las grandes cráteras de campana decoradas con escenas dionisiacas o de banquete; copas adscritas al grupo de Viena 116 y escifos del grupo del Fat Boy. En la región turdetana, los vasos de figuras rojas son minoritarios y faltan las grandes cráteras. En la zona púnica, desde Almería a Cádiz, las importaciones más numerosas son los vasos de barniz negro y formas no relacionadas directamente con el consumo del vino. En el sureste, aunque están presentes las copas y cráteras de figuras rojas, predominan las importaciones de barniz negro y en especial una de sus formas: el cántaros (Cabrera, 1995: 139-156). Según señalan Olmos y Sánchez, el cántaros, en Grecia, fue el vaso de los héroes y es posible que el simbolismo heroizador llegara también al Extremo Occidente donde se preferirá como vaso funerario (Olmos y Sánchez, 1995: 107-136).

El comercio con el mundo griego facilitó la entrada de nuevas expresiones culturales que fueron dinamicamente interpretadas por las sociedades ibéricas (Cabrera y Sánchez, 2000: 133).

La frecuente asociación de cráteras de campana, copas y cuencos hace pensar a las Dras. Cabrera y Sánchez que muy probablemente estos vasos fueron fabricados por un mismo taller que distribuía sus productos en mercados periféricos, y que de alguna manera este taller ático modificó su producción adaptando los tamaños de sus vasos y la iconografía a la lejana clientela ibérica (Cabrera y Sánchez, 2000: 138).

La presencia de cerámica ática comienza a disminuir hacia el tercer cuarto del siglo IV, momento en el que se documentan los últimos vasos áti- cos junto a otros de procedencia apulia o campana, que a partir de ese momento desaparecen para siempre (Cabrera y Sánchez, 2000: 140).

En cuanto a los vasos de pie bajo o cilicas del grupo del Pintor de Viena 116, éstos se caracterizan por ser recipientes de escasa calidad, como el resto de la producción del siglo IV a.C. Reciben este nombre por su similitud a un vaso del Museo de Viena con número de inventario 116. Esta falta de calidad la vemos reflejada no sólo en la realización de la copa, sino también en la decoración. Se trata de piezas producidas en serie.

El estudio de G. Trías sobre la cerámica griega documentada en el barco del Sec y en concreto sobre las cilicas, permite señalar las características formales e iconográficas de estos recipientes. Se trata de vasos sin labio marcado, poco profundos, de paredes finas, de pie bajo y sin peana y de tamaño pequeño. La decoración se realiza en el medallón central del interior del vaso y en el exterior. Se trata de escenas muy simples y esquemáticas, con dibujo rápido, descuidado y a veces irreconocible. Los motivos decorativos están constituídos por un repertorio limitado.

Las caras exteriores están decoradas con escenas de palestra. Los jóvenes aparecen envueltos en los mantos, mirándose el uno al otro, ambos en actidud del erómenos. En ocasiones la rigidez se rompe y uno de ellos se destaca sujetando algún elemento o bien ofreciendo al compañero un objeto de la palestra en actitud erastés (Cabrera y Rouillard, 2004: 94). Se trata de figuras deformes y achaparradas, ubicadas entre las asas. Se dibujan a ambos lados de la copa, colocados simetricamente.

En cuanto a la decoración interior y concretamente en el medallón central se pueden establecer tres grupos: A.- Jóvenes vestidos o desnudos frente a un altar o pila. El joven suele ir vestido con himatión vuelto a la derecha, distinguiéndose bien la cabeza con la masa de cabellos - el ojo marcado y abierto y la ceja encima- y el brazo derecho en posición extendida delante de un pilar, altar o de una pila en la palestra. A veces el jóven aparece desnudo en una actitud similar, con un aribalo en la mano y delante, como en el caso anterior del pilar o terma de la palestra.

Estas figuras masculinas han sido interpretadas como las representaciones de atletas ante altares o ante pilas, como se ha señalado líneas arriba. Tenemos conocimiento de que los atletas 
tenían costumbre de efectuar juramentos en la palestra, antes de entrar en los juegos, y éstos se realizaban con la mano extendida sobre el altar. En cuanto a la pila para las abluciones (loutron) se reducía a una construcción pequeña y sencilla. Se ha sugerido que, además de agua, pudieron contener aceite. Las figuras también suelen ir acompañadas por elementos que, normalmente son característicos de los atletas: los discos y los aribalos. Los discos, por lo general, se representan en las manos de los atletas, pero también pueden ocupar el lugar del altar o pila o aparecer por duplicado detrás de su cabeza. Los aribalos, vasitos indispensables para cualquier atleta, se reduce a un círculo grueso con un punto en el centro, a veces el joven lo sujeta con una cuerda, colgado de la mano o bien éste se halla frente a él. Otro motivo acompaña a estas escenas -un edículo- que Trías interpreta como una fuente con su caño marcado (Figuras n ${ }^{\circ} 10,11,12,13$ y 14).

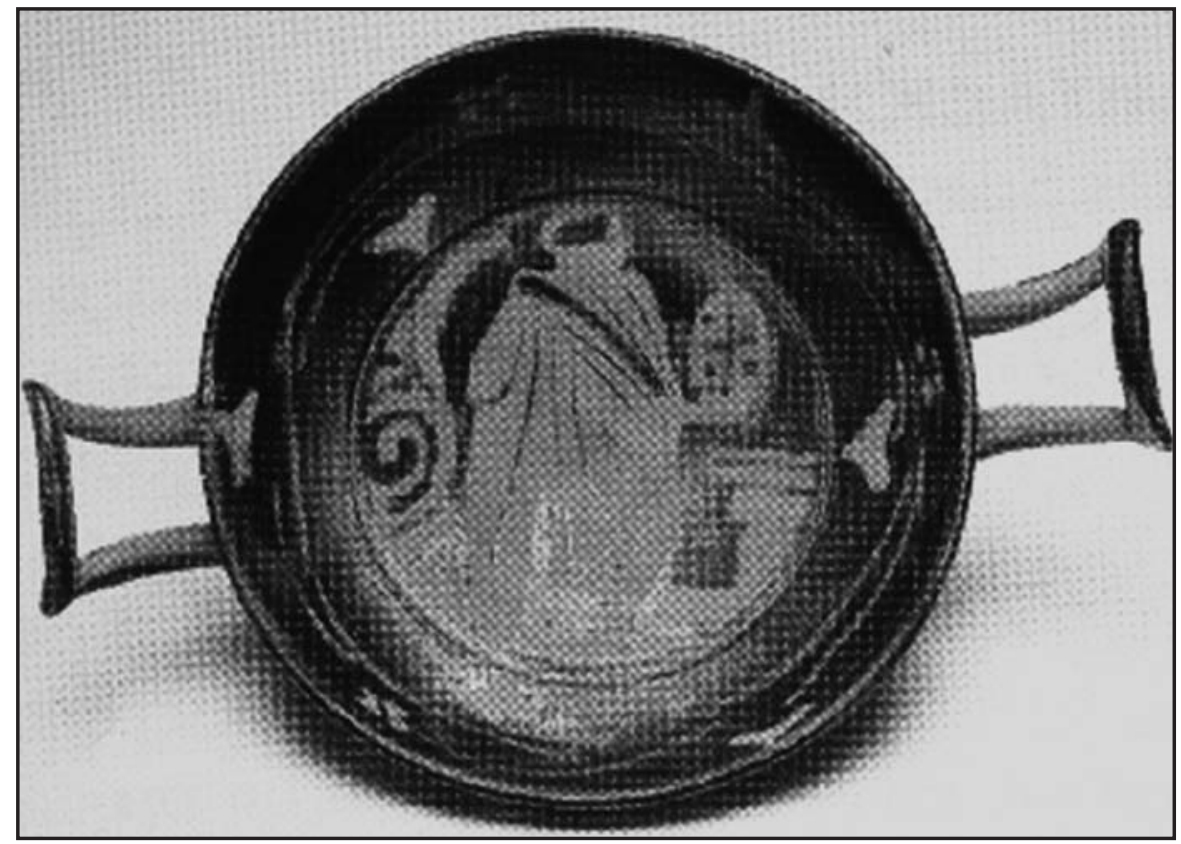

Figura $n^{\circ}$ 10.- Cilica del Grupo de Viena 116 documentado en la necrópolis de Baza (Granada). Decoración exterior.

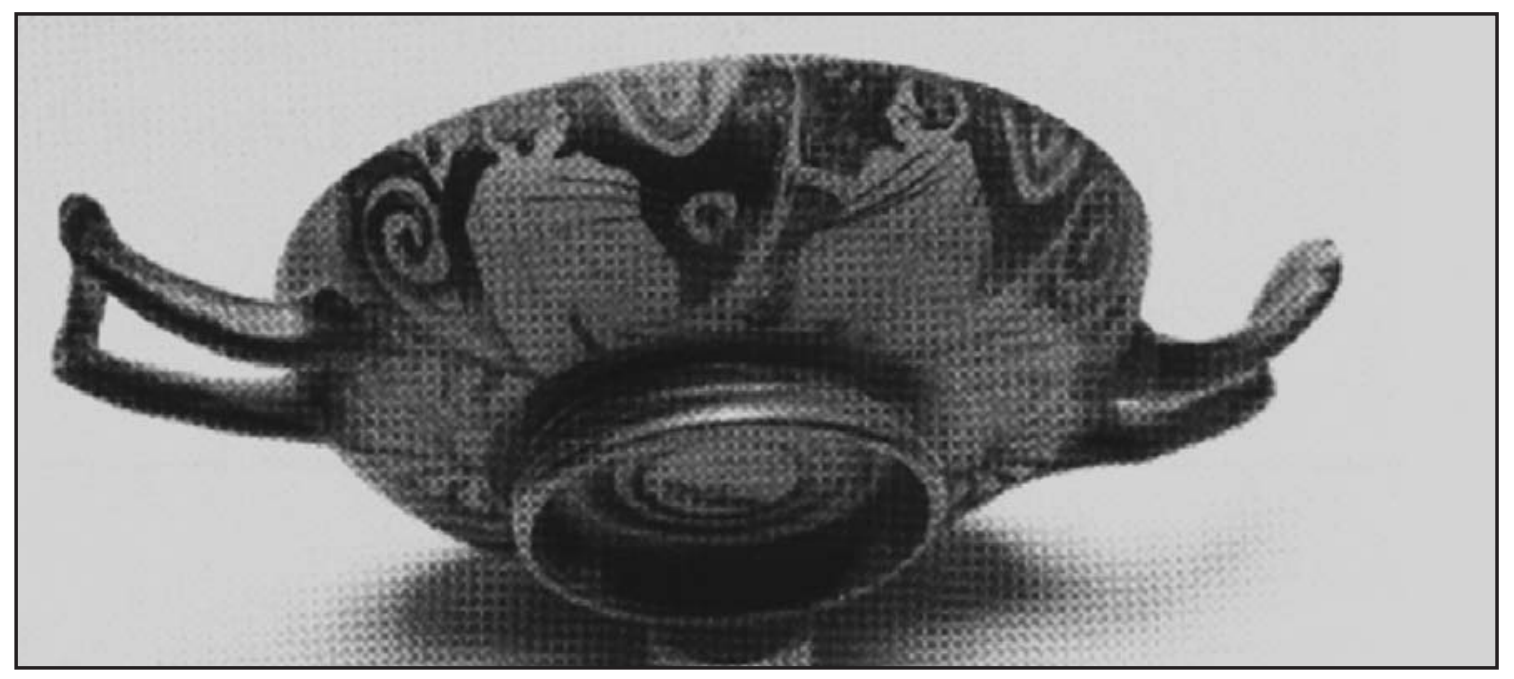

Figura $n^{o} 11$.- Cilica del Grupo de Viena 116 documentado en la necrópolis de Baza (Granada). Decoración exterior. 


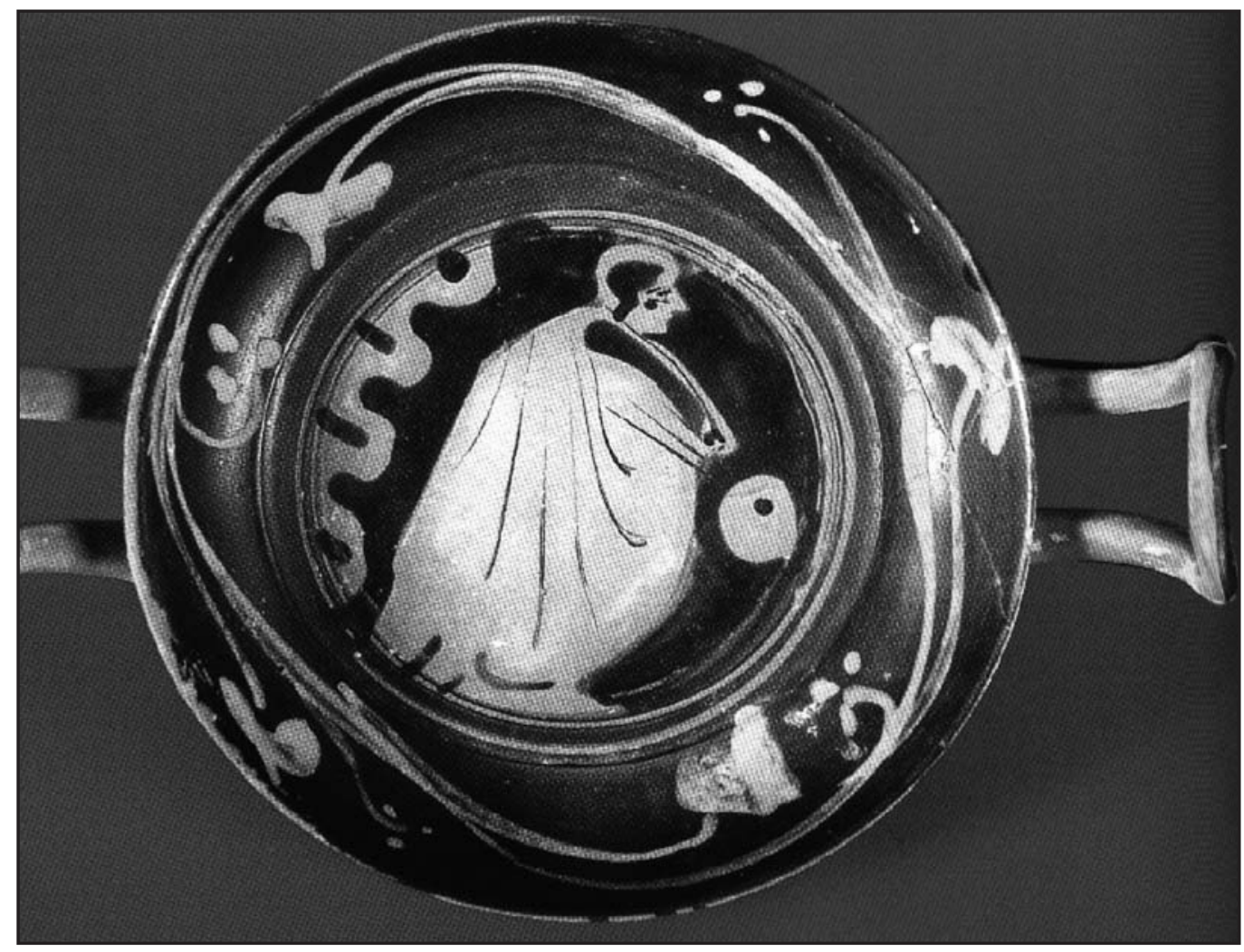

Figura $n^{\circ}$ 12.- Cilica del Grupo de Viena 116 documentada en la necrópolis de El Cigarralejo (Mula, Murcia)

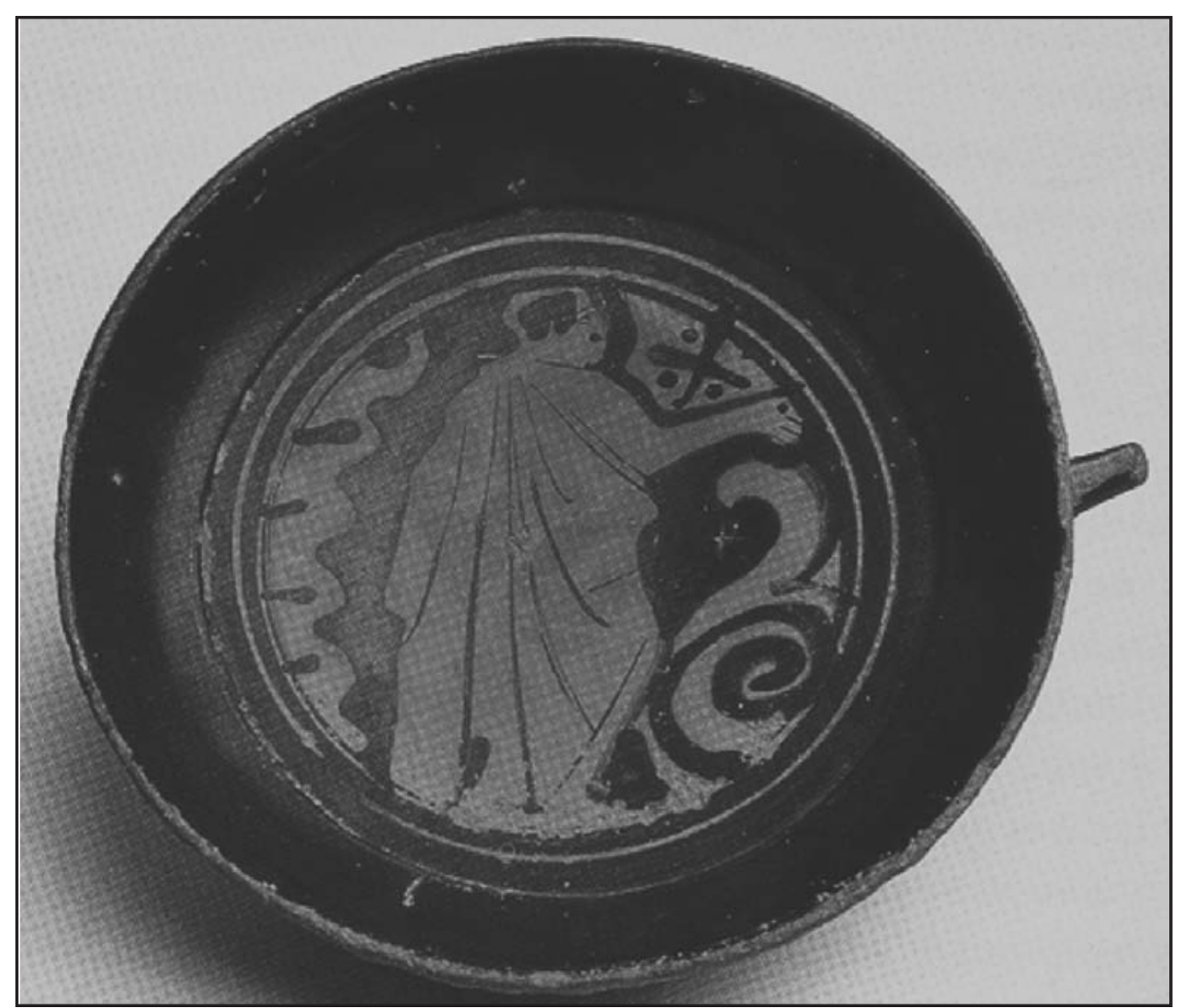

Figura $n^{\circ}$ 13.- Cilica del Grupo de Viena 116. 


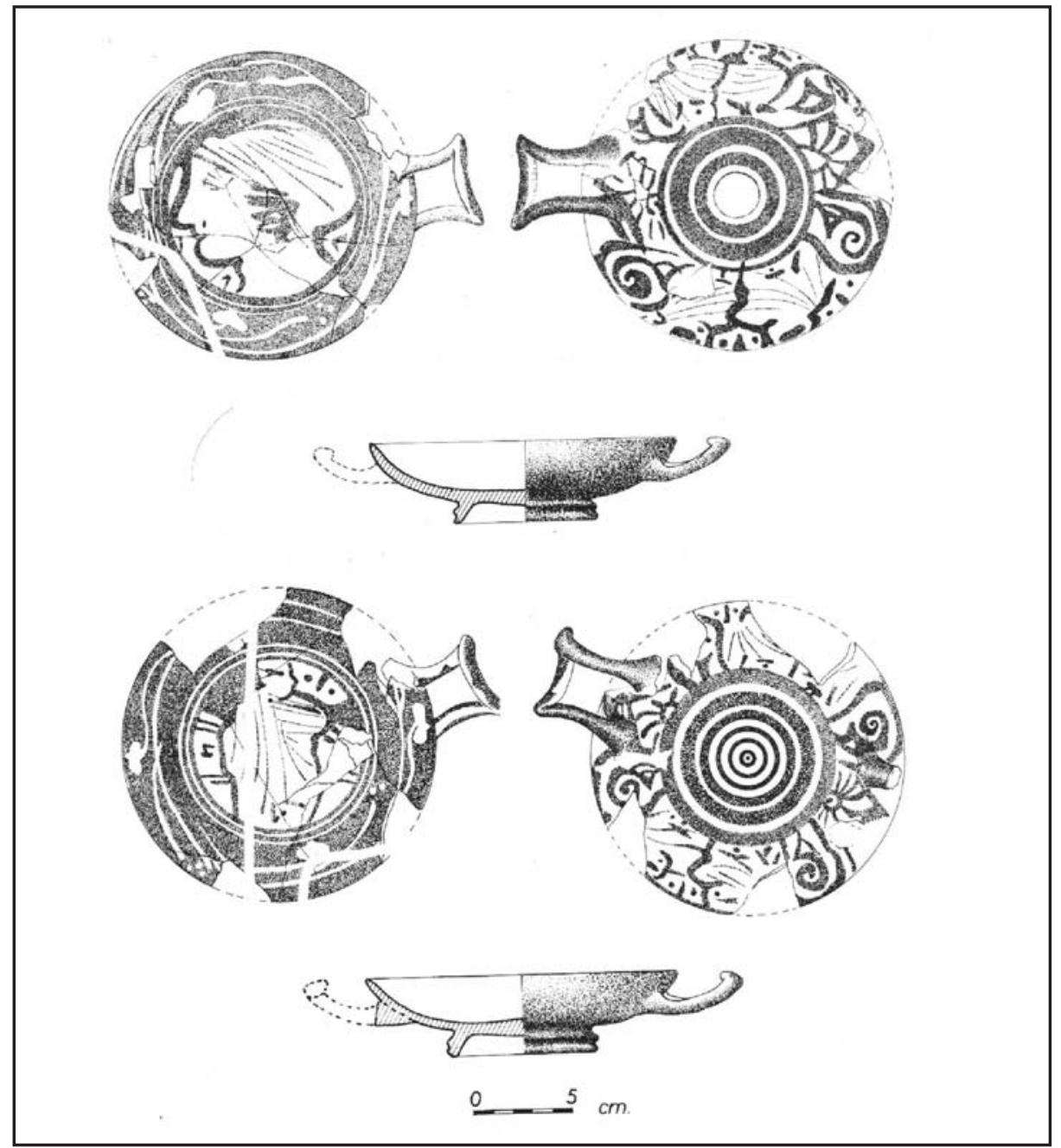

Figura $n^{\circ}$ 14.- Dibujos de cilicas del grupo de Viena 116 documentadas en la necrópolis de El Cigarralejo. Grupo 1 y 2 de Trias y Variantes I y II de Rouillard.

B.-El segundo grupo se halla decorado con cabeza femenina o masculina, aislada o acompañada por otras figuras, que se representa vuelta hacia la izquierda o hacia la derecha, y se ha relacionado con un prototipo metálico, más lujoso y menos frecuente, que tendría como decoración una moneda en el medallón central. La imagen de mujer se ha interpretado como Artemis o Afrodita. El espacio frente al perfil de la cara se rellena con una línea ondulada y el situado detrás de la nuca está ocupado por un triángulo (Figura $\left.\mathrm{n}^{\mathrm{o}} 15\right)$. En cuanto a la efigie masculina suele ir tocada con gorro frigio.Todos están vueltos hacia la derecha, con roleo o voluta delante y una línea ondulada detrás (Figura $\mathrm{n}^{\circ}$ 16) (Arribas, Trias et alii, 1987: 72-85). C.- El tercer grupo iría decorado con protomos de grifo (Figura $\mathrm{n}^{\circ} 17$ )

P. Roillard estudió las copas de pie bajo del grupo de Viena 116 documentadas en la Península y, al igual que G. Trias, distinguió dos variantes: Variante I: se trata de escenas repetitivas y estereotipadas de palestra, con jóvenes atletas desnudos o vestidos, con objetos en las manos propios del mundo del deporte, tales como estrigiles o aribalos, que se dirigen a un tercer personaje, un jóven, un adolescente, objeto de amor y habitualmente representado en actitud de espera. En el fondo ideal del vaso se representan objetos característicos de la palestra. En el exterior se representan dos parejas de jóvenes afrontados y palmetas debajo de las asas. El origen y significado de estas escenas de encuentran en el siglo $\mathrm{V}$ a.C. (Sánchez, 1996: 76 y ss.). Variante II: la decoración del medallón consiste en una cabeza femenina y en el exterior dos cabezas o una sola y un joven envuelto en un gran manto. Se trata de una variedad menos frecuente que la anterior.

Como se ha señalado anteriormente para la cerámica ática del siglo IV a.C., las copas de pie bajo fueron fabricadas en Atenas para la 


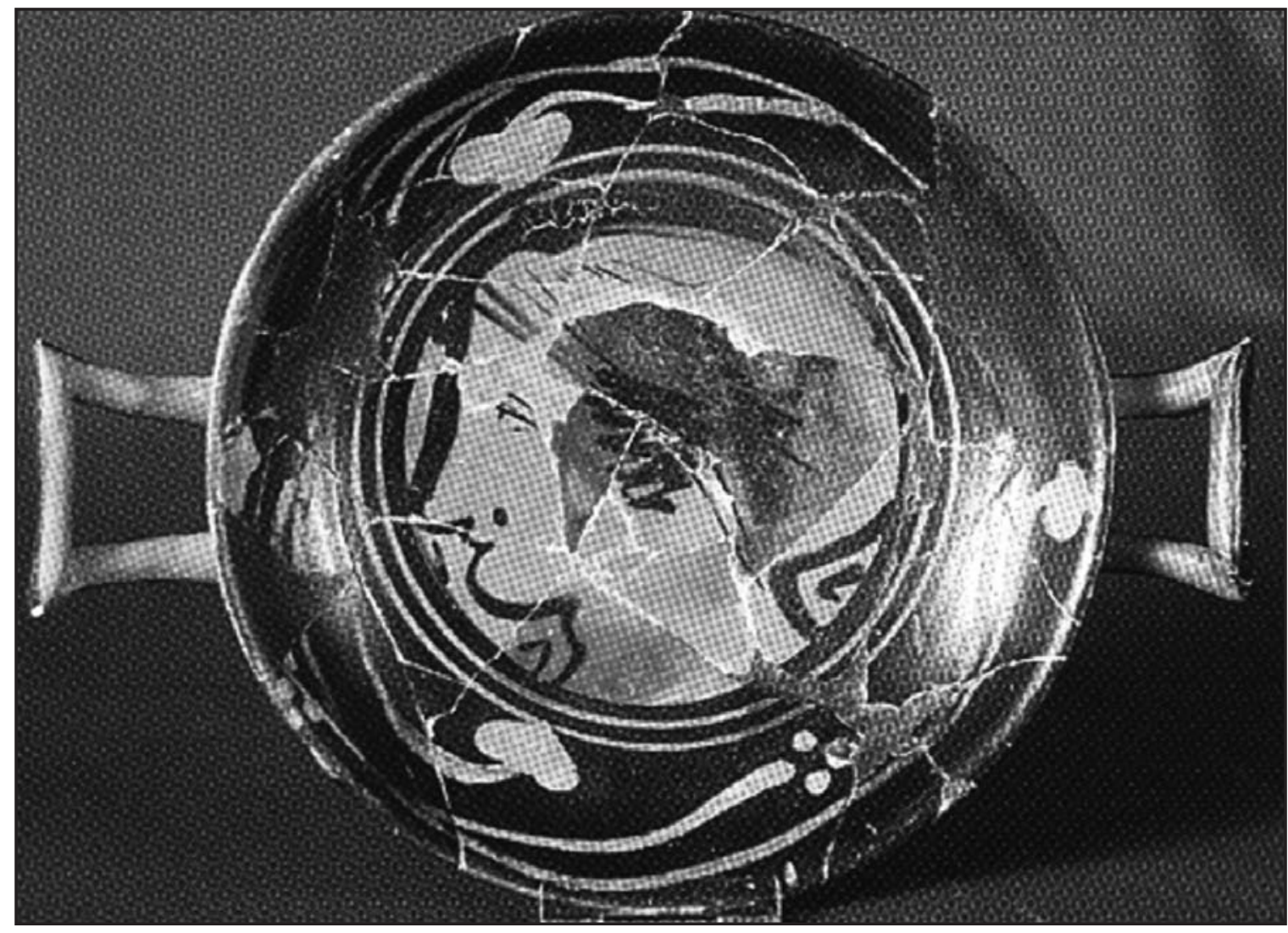

Figura $n^{\circ} 15$.- Cilica Grupo de Viena 116 documentada en la necrópolis de El Cigarralejo. Grupo 2 de Trias y Variante II de Roiullard. Busto femenino.

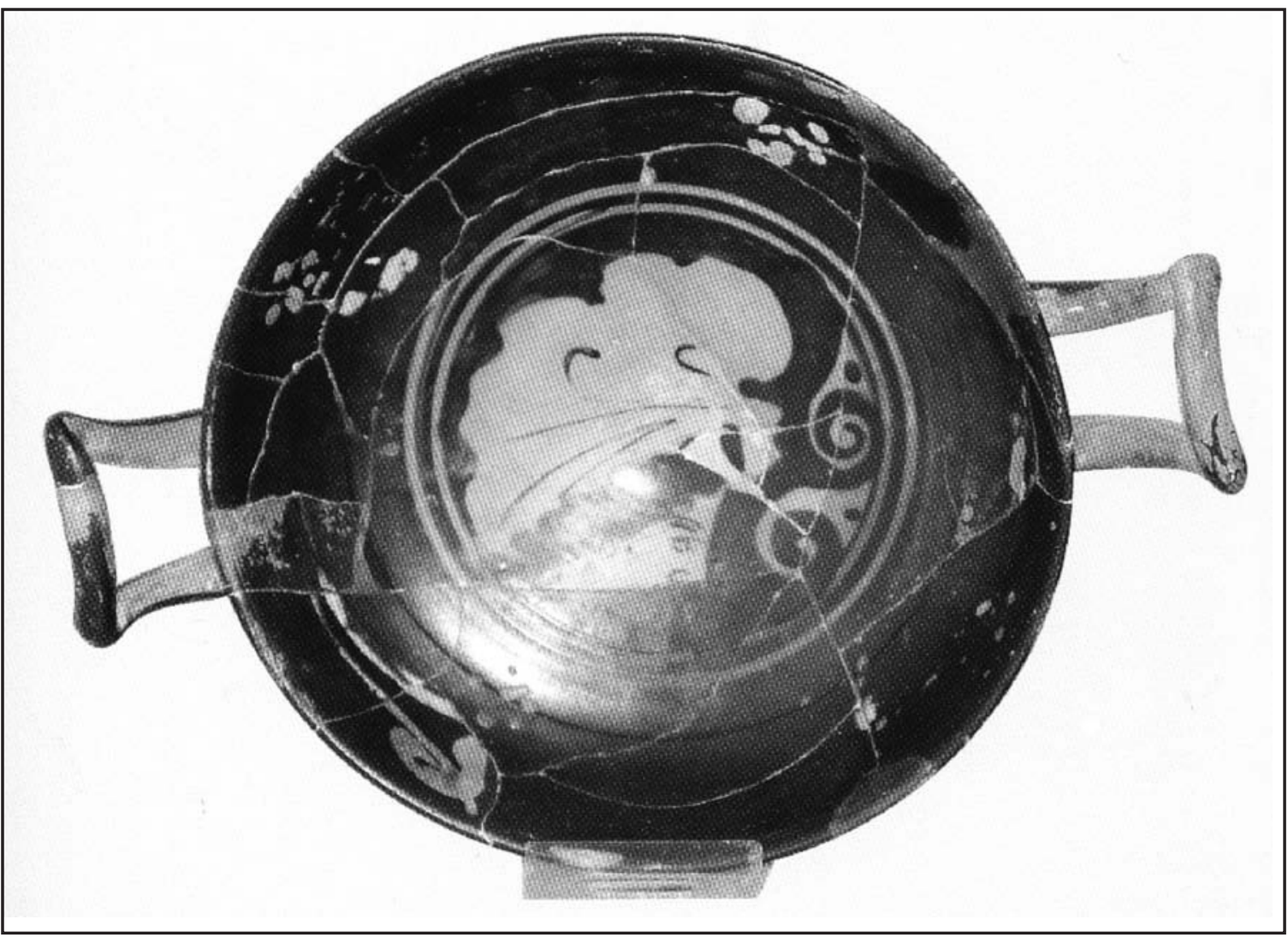

Figura $n^{o}$ 16.- Cilica Grupo de Viena 116 documentada en la necrópolis de El Cigarralejo. Grupo 2 de Trias. Variante II Rouillard. Busto masculino con gorro frigio. 


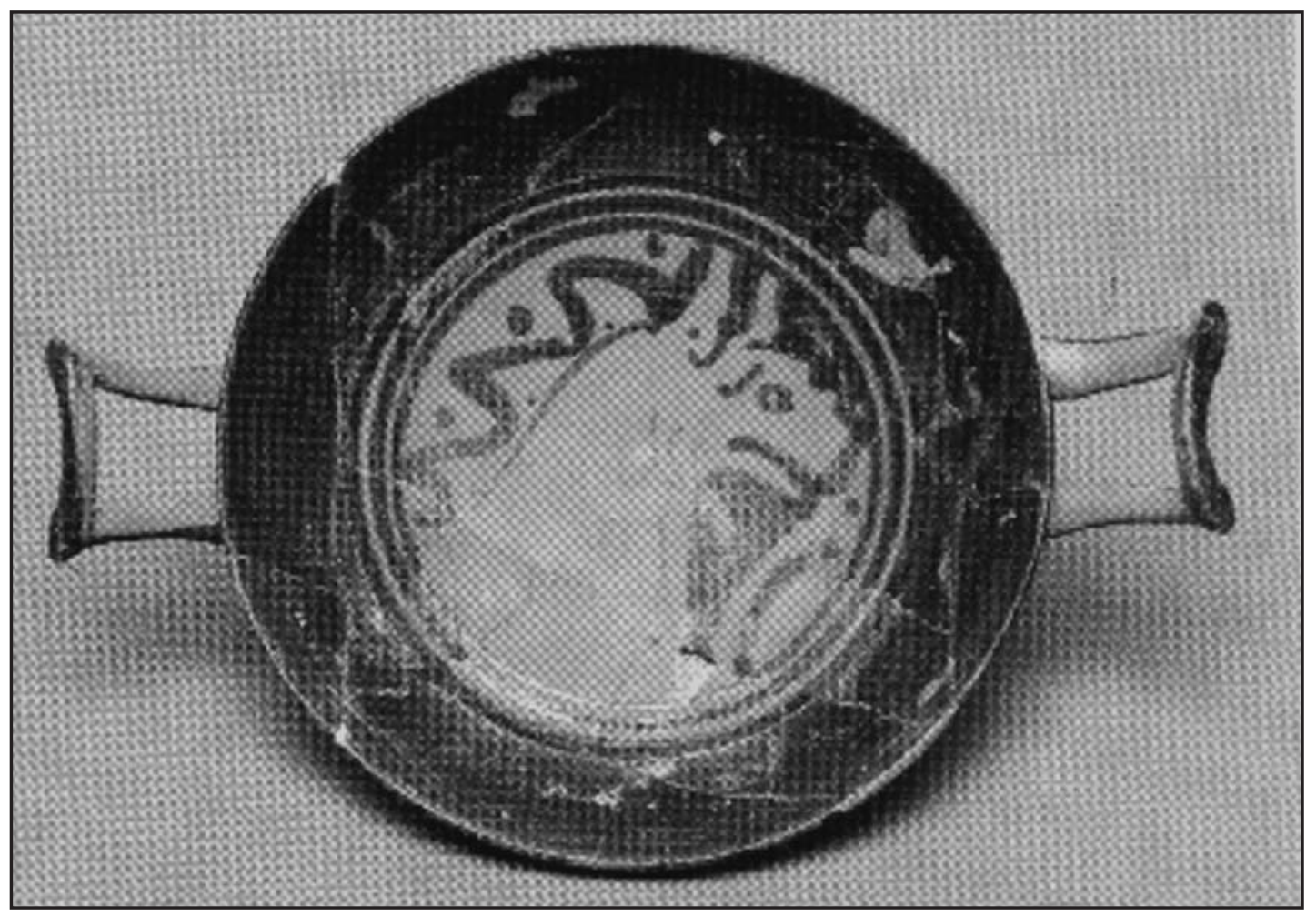

Figura $n^{o}$ 17.- Cilica grupo de Viena 116 documentada en la necrópolis de Pozo Moro (Albacete).

exportación hacia el Occidente Mediterráneo, un mercado menos exigente que el de otras partes del Mediterráneo.

Los pintores del Grupo de Viena 116 trabajaron en el mismo taller que los Pintores del Grupo de Telos (Pintor de Telos, Pintor de la Grifomaquia de Oxford, Pintor del Bizco, Pintor del Tirso Negro y Pintor de Toya) y que el Grupo Fat Boy, éstos últimos autores de un gran número de escifos con decoración muy similar a la de las copas del Grupo de Viena 116, ya que en ellos se repite, de forma constante, la misma escena del mundo de la palestra (Figura $n^{\circ} 18$ ).

Para C. Sánchez en este taller, también debieron fabricarse vasos de barniz negro, en concreto, pateras de borde saliente utilizados como tapaderas de las crateras de campana que contenían las cenizas del difunto en las necrópolis ibéricas andaluzas. Para Cabrera y Rouillard son varios los factores que permiten plantear la existencia de este gran taller ateniense en la primera mitad del siglo IV: su distribución occidental; la asociación de tres tipos diferentes de vasos (crateras de campana, pelices, copas y escifos) (Cabrera y Rouillard, 2004: 91-95).

Las copas del Grupo de Viena 116 fueron muy bien aceptadas por los mercaderes ibéricos, dis- tribuyéndose por Andalucía, Murcia y País Valenciano, sobre todo en el segundo cuarto del siglo IV a.C., no sólo en necrópolis, donde pueden aparecer en las tumbas más ricas acompañando vasos de mayor calidad, sino también en poblados (García i Martín, 1996: 468). Prácticamente en ningún yacimiento fuera del mundo ibérico se han documentado, si exceptuamos, entre otros ejemplos, el documentado en el yacimiento conquense de Alvar Fáñez.

A continuación recogemos, de forma somera, algunos ejemplos de copas de pie bajo del Grupo del Pintor de Viena documentados en la Península Ibérica:

Provincia de Gerona: Ullastret: M. Picazo cita la existencia de cinco ejemplares, que corres-ponden al estilo más tardío de figuras rojas y se fechan en la primera mitad del siglo IV a.C. (Picazo, 1977, no $156,157,162,163$ y 104, p. 5961)

Provincia de Valencia: Se documentan en La Bastida de les Alcuses (Trias, 329) y en la cuevasantuario dels Pilars. Junto a un lote importante de ollas de cerámica ibérica de cocina y un pequeño conjunto de cerámica decorada con motivos geométricos (cuencos, platos y urnas) así como recipientes de cerámica común (ánforas y 




Figura $n^{\circ}$ 18.- Sciphos del pintor denominado Fat Boy documentada en el necrópolis de El Cigarralejo (Mula, Murcia).

tinajas), se documentó un pequeño lote de piezas de importación ática de figuras rojas y barniz negro: ánfora de figuras rojas del siglo V a.C.; una copa de pie bajo del Grupo del Pintor de Viena 116 y un borde de cratera de campana (Grau Mira, 2000: 206).

Provincia de Alicante: Tossal de Manises: Contamos con un ejemplar depositado en el Museo Arqueológico Provincial de Alicante, $\mathrm{n}^{\mathrm{o}}$ inv. TM 18005 (García i Martín, 1996: 468). Illeta dels Banyets (EI Campello, Alicante): Las copas del Pintor de Viena son las más representadas en el citado yacimiento. Se han documentado dieciocho fragmentos que corresponden a nueve piezas (García i Martín, 1997: 182-183). Cabezo Lucero (Guardamar del Segura): La cerámica griega está presente desde el 500/475, con piezas de figuras negras. Sin embargo, el mayor número de vasos griegos documentados se fechan a partir del 375 hasta el 325 a.C. Aunque hay una preponderancia de la cerámica ática de barniz negro, también podemos señalar la existencia de 65 piezas de figuras rojas pertenecientes a vasos contenedores o para servir; vajilla de mesa y vasos para el tocador o para ofrendas funerarias. El mayor número de piezas corresponden al grupo del Pintor de Viena 116, al igual que en otras partes de la Península, aunque hay otros pintores constatados, como el Pintor de Iena, el Pintor Q, etc. (Rouillard, 1993: 87-94). Las piezas del grupo de Viena 116 se han fechado entre el 375-350 a.C. y se documentaron en los puntos denominados: punto 12 (pp. 164-165); 41 (pp. 201-201); 51 (pp. 222-223); 80 (pp. 250-251); Z2 (pp. 279) y A5 (pp. 296) (VVAA, 1993). Poblado de La Picola (Santa Pola): El poblado de La Pícola se planteó y realizó de una sola vez. Se trata de un establecimiento comercial que necesitó fuertes defensas para proteger las mercancías almacenadas. La cerámica ática no es tan abundante como en la necrópolis contemporánea de Cabezo Lucero, no obstante, se observa una gran variedad de formas; son principalmente vasos para beber (copas Cástulo y del pintor de Viena 116, a los que cabe añadir algunos vasos grandes de figuras rojas, como cráteras y ánforas y vasos contenedores de perfume) (Moret et alii, 1996, 403). La Albufereta (Trias, 366, $\mathrm{n}^{\circ} 4$ ). Necrópolis de El Puntal (Salinas). En la incinerarción $\mathrm{n}^{\circ} 23$ se documentaron diversos fragmentos de figuras rojas que fueron catalogados por Rouillard como una cilica del pintor de Viena 116 y una copa de escifos (Sala Sellés y Hernández Alcaraz, 1998: 235). 
Provincia de Murcia: Necrópolis de El Cabecico del Tesoro (Verdolay, La Alberca). Se han documentado dos piezas procedentes de las tumbas 184 y 558, fechadas entre finales del primer cuarto del siglo IV a.C. (García Cano, 1982: 64, n ${ }^{\circ} 26$ y 27). Las Cabezuelas (Totana): Se documentó una pieza, perteneciente a un pie. La pieza, en paradero desconocido y perteneciente a una colección particular, fue fechada en el segundo cuarto del siglo IV a.C. (García Cano, 1982: 113, n 150). Necrópolis de El Cigarralejo (Mula): La cerámica ática de El Cigarralejo se inserta en el horizonte de las importaciones griegas del siglo IV a.C., que tan abundates son en el área ibérica peninsular desde Cataluña hasta Andalucía, incluyendo la rica zona del sureste. El predominio casi absoluto corresponde a los productos de barniz negro, aunque también existen figuras rojas. Entre éstas se documentaron piezas, procedentes de las sepulturas 197, 204, 200, 280 y 380. Todos los ejemplares fueron fechados en el primer cuarto del siglo IV a.C. (García Cano: 1982, 134-135 y 138-139, n ${ }^{\circ}$ 197,202 y 204) Las piezas suponen el 82 '4\% de las copas de figuras rojas y un $70 \%$ de los vasos figurados. Están caracterizadas por tener ancha boca con borde recto y cuerpo poco profundo. Por lo que respecta a la decoración, suelen pintarse en el labio interno del borde una guirnalda de hojas de hiedra alternando con frutos unidos por tallos de pintura blanca superpuesta, que ocupa el espacio existente entre el borde y la acanaladura que delimita el medallón central. El tema principal figurado, situado en el medallón, tiene como elemento más representado un jóven cubierto por himation cuyos rasgos anatómicos y esquema general es bastante tosco frente a un altar o pilar. Un segundo motivo, aunque menos frecuente, corresponde a una gran cabeza femenina de perfil. En el exterior las escenas dibujadas representan más comunmente parejas de efebos envueltos en mantos enfrentados o una gran cabeza femenina que sustituye a uno de los dos personajes, que llega a ocupar todo un lateral. Completan la decoración una gran palmeta enmarcada por roleos debajo de cada asa. Todas las cilicas se pueden adscribir al grupo del Pintor de Viena 116, con variantes decorativas I y II de Rouillard, a excepción de una que este investigador francés considera que pertenece al pintor del El Cigarralejo (García Cano, 1998: 162-163; García Cano, 2005: 77-86 y Cuadrado 1987). La Loma del Escorial (Los Nietos, Cartagena): En la excavación del departamento B de la Loma del Escorial se documentó un único fragmento de figuras rojas identificado como una cilica, en concreto un borde. En el interior del labio se aprecian los característicos tallos y hojas en pintura blanca sobrepintada, motivo muy repetido en la decoración subsidaria de este tipo de copas, con estilo poco cuidado. En la cara externa se observa la parte superior de un manto, probablemente correspondiente a la espalda de un efebo envuelto en himatión, cuyos pliegues se señalan por varias líneas de barniz negro diluído. A la derecha aparece un disco colgado en la pared representado de forma esquemática. Aunque el tamaño del fragmento impide al investigador afirmar con total certeza el taller al que debió de pertenecer, los rasgos descritos le hacen sugerir que sea una pieza perteneciente al grupo del Viena 116, con cronología de la primera mitad del siglo IV a.C. (García Cano, 1997: 261). En Coimbra, como en otros grandes oppida del sureste peninsular se han documentado principalmente copas para beber en fiestas y actos de gran relevancia cultual como "khantharoi, bolsales, kylikes y skyphoi", éstos dos últimos tipos con figuras rojas de los talleres del Grupo de Viena 116 y del Fat Boy y una veintena de fuentes, platos, escudillas y saleros de barniz negro, es decir, piezas de vajilla de mesa en grandes cantidades, que por lo general tuvieron una larga utilización. La mayor parte de estas cerámicas, después de usarse un tiempo fueron depositadas en los ajuares funerarios de las tumbas de los propietarios del vaso o miembros de la familia como símbolo de estatus, pertenencia o prestigio (30 años de investigaciones en Coimbra del Barranco Ancho, Jumilla). Necrópolis de El Poblado (Coimbra del Barranco Ancho, Jumilla), junto a diversos tipos de cerámica ática destacaremos un fragmento de borde de crátera de campana y una copa de pie bajo del grupo de Viena 116, fechada en la primera mitad del siglo IV a.C. (García Cano y Page del Pozo, 1994: 222223 y García Cano y Page del Pozo, 2007: 29). Necrópolis de La Senda (Coimbra del Barranco Ancho, Jumilla): junto a diversas importaciones griegas nos interesa resaltar cuatro copas de pie bajo del grupo de Viena 116 (García Cano y Page del Pozo, 1994: 224) y en Cabezo de Tío Pío (Archena) también se han documentado estas piezas, tan frecuentes en la Península Ibérica (García Cano y Page del Pozo, 1994: 224). Necrópolis de Castillejo de Los Baños (Fortuna): En la tumba $n^{\circ} 30$ se documentó una 
cilica de pie bajo del grupo del Pintor de Viena 116 (García Cano y Page del Pozo, 2001: 103). En el Museo Histórico Minero Príncipe Felipe de Borbón y Grecia se conserva una cilica ática de figuras rojas del grupo de Viena 116 que pudo haberse encontrado en Cartagena o en Huelva (Calvo Pérez, s.a:, 97).

Provincia de Albacete: Necrópolis de El Salobral: Se documentaron junto a las cilicas de pie bajo, ocho formas más, entre las que podemos señalar: cráteras, escifos, cilica-escifos, bolsales, lecitos, lecanides, páteras y platos. Todas las piezas se fechan en el segundo cuarto del siglo $\mathrm{V}$ a.C.; piezas que ponen de manifiesto la importancia comercial y cultural del sureste de la meseta, y en concreto de la provincia de Albacete a lo largo de la primera mitad del siglo IV a.C. (Blánquez, 1995: 204 y García Huerta, 1995: 98). Llano de la Consolación: El conjunto cerámico griego hallado en esta necrópolis es un grupo de gran variedad tipológica. La mayor parte de las piezas catalogadas son de barniz negro (copas Cástulo y de estilo delicado, bolsales, escifos, páteras y fuentes), aunque también existen algunos ejemplares decorados con figuras rojas, como copas del ciclo del Pintor de Viena 116, copas del ciclo del Pintor de Penthesilea, quizá del pintor de Bolonia 417. Esta necrópolis tuvo su mayor apogeo en la primera mitad del siglo IV a.C., como indican estos materiales, sin embargo existe una total ausencia de vasos contenedores de aceites o perfumes como pelices o lecitos, que suelen llegar con gran fluidez a la península (Valenciano Prieto, 1998: 25-26).

Provincia de Almería: Villaricos (Rouillard, 1975).

Provincia de Málaga: Cerro del Mar (Torre del Mar) (Rouillard, 1975).

Provincia de Cádiz: Mesas de Asta (Jerez) (Rouillard, 1975)

Provincia de Huelva: Cabezo de San Pedro (Rouilard, 1975)

Provincia de Granada: Baza: Se ha documentado un gran número de vasos del grupo de Viena 116. Los hallazgos se realizaron en las tumbas $\mathrm{n}^{\circ} 43,67,76,82,96$ y 128; en los ustrina B1; B2; B3 y fragmentos hallados en superficie (Presedo Velo, 1982: 283-285, fig. 50, lám. XIX, 51, lám. XX, fig. 53, lám. XVIII; fig. 54, lám. XVIII; 95; 87; $113.5 ; 215 ; 216,214,77$ y 146). Se han hallado en Cerro de El Real (Galera)
(Rouillard, 1975: 30, $\mathrm{n}^{\circ}$ 10) y en Mirador de Rolando (Rouillard, 1975).

Provincia de Jaén: Castellones de Ceal (Hinojares): Los cuatro ejemplos documentados proceden del interior de una tumba cubierta por tres capas de adobes. Formaban parte del ajuar varios vasos de cerámica ática de figuras rojas, además de tres urnas ibéricas, una falcata, una lanza y cuatro tabas (Blanco Freijeiro, 1957: 109111, no 5, 6 y 7 y Rouillard, 1975: 1-4, 26). Los estudios de Carmen Sánchez sobre la cerámica ática aparecida en el transcurso de las excavaciones de $\mathrm{C}$. Fernández Chicarro recogen cinco ejemplares ( $\mathrm{n}^{\mathrm{o}}$ inv. 111 y 117, así como otros tres sin número de inventario) y señalan que las importaciones áticas, en este yacimiento, abarcan desde el último cuarto del siglo $\mathrm{V}$ hasta mediados del siglo IV a.C., aunque la mayoría se fechan en el segundo cuarto del siglo IV y la forma más frecuente es la copa de pie bajo de figuras rojas y, junto a ellas, las cráteras de campana y páteras de barniz negro, los tipos más frecuentes en toda el área andaluza (Sánchez, 1998: 192,193, 194 y 199). La Guardia: Rouillard documenta dos ejemplares (1975: 26-27, $\mathrm{n}^{\mathrm{o}}$ 5-6). Cástulo: (Rouillard, 1975: 29, no 7, 8, 9). C. Sánchez estudió los ejemplares documentados en la necrópolis de Estacar de Robarinas. Se trata de siete copas números 15 (enterramiento I),16 (enterramiento V), 17 (enterramiento II), 18 (enterramiento IX), 19 (enterramiento V), 20 (enterramiento X) y 21 (enterramiento IX). La citada investigadora señala que los ajuares áticos de esta necrópolis destacan frente a otros yacimientos andaluces por su riqueza y tipología. La mayoría de las piezas con decoración figurada son, junto a éstas del grupo de Viena 116, las del Pintor de El Cigarralejo (Sánchez, 1988: 282, 284, 285, 286, 287 y 308). Finalmente, hay que citar también Toya (Rouillard, 1975: 30); Puente de Tablas (Ruiz Rodriguez, 1994) y El Pajarillo (Huelma, Jaén), de donde proceden dos copas de figuras rojas del grupo de Viena 116 ( Molinos Molinos, 1998: 101 y ss.)

Provincia de Córdoba: Cerro de la Cruz (Almedinilla) (Rouillard, 1975: 30) y Colina de los Quemados (Rouillard, 1975: 30).

Provincias de Cáceres y Badajoz: En Medellín y en concreto en el conjunto del Cerro del Castillo y sus inmediaciones, donde se asentó un poblado junto al que se instaló una necrópolis de cremación, se documentó una cerámica ática 
de época arcaica conocida como Kylix de Medellín, atribuída a Eucheiros, pintor del Grupo de Pequeños maestros que trabajaron objetos de gran calidad, así como un aríbalos corintio, cerámica de barniz negro del siglo $\mathrm{V}$ y copas de pie bajo, éstas últimas las piezas más abundantes. Según señalan Jiménez Ávila y Ortega Blanco, adoptan las decoraciones pintadas propias del estilo del Pintor de Viena 116 (Jiménez Ávila y Ortega Blanco, 2006, 105-40).

Se han localizado vasos del Grupo de Viena 116 en los castros prerromanos de la II Edad del Hierro, tanto de la provincia de Cáceres como de Badajoz y tanto en zonas de hábitat como en las necrópolis, dando fe del aprecio de que eran objeto por parte de las poblaciones de la época. Así se han documentado en Capote, Botija y Alcazaba de Badajoz (Jiménez Ávila y Ortego Blanco, 105-140).

Provincia de Ciudad Real: Motilla de las Cañas. Se trata de un yacimiento muy característico del denominado Bronce Manchego en el que, tras una prolongada etapa de abandono, se desarrolló un asentamiento ibérico representado por diversos fragmentos de cerámica ibérica pintada, cerámicas grises y pequeños recipientes de pasta vítrea muy fragmentados. Dentro de esta etapa también se han documentado varios fragmentos de cerámica griega (García Huerta y Morales Hervás, 1999: 337). En concreto se documentó una cilica de figuras rojas, junto a escifos, cilicas de barniz negro y una pelike de figuras rojas (García Huerta y Morales Hervás, 1995: 117-125). Sus investigadores fechan estas piezas entre finales del siglo $\mathrm{V}$ y mediados del siglo IV a.C. La Bienvenida (Almodovar del Campo): Este yacimiento identificado con Sisapo ha aportado, desde que se inició su excavación sistemática a principios de los años 80 , uno de los conjuntos de cerámicas griegas más interesantes de la meseta. La presencia de cerámica griega comprende un amplio periodo cronológico, desde la primera mitad del siglo VI a.C. hasta el siglo IV a.C. En relación a las cerámicas del siglo IV a.C. nos interesa resaltar la presencia de varios ejemplos de cilicas de figuras rojas pertenecientes al Grupo del Pintor de Viena 116 (García Huerta y Morales Hervás, 1999: 336). Las piezas se documentaron en el estrato 7c A1 (BV/91/ 4043; 4239;4207; 4053 y 4065) (Fernández Ochoa et alii, 1994: 92 y ss.). La asociación de estas copas áticas de figuras rojas con pie bajo y labio recto con cráteras ha permitido a los investigadores de Sisapo a incluir este enclave dentro de una dinámica de importaciones muy similar a la documentada en Cástulo durante el segundo cuarto del siglo IV a.C. y a la imperante en el área oretana septentrional (Zarzalejos et alii, 2004: 70). En Alarcos: junto al yacimiento anterior ofrece un interesante conjunto de cerámicas griegas. El marco cronológico de las cerámicas griegas importadas se sitúa entre finales del siglo VI y la primera mitad del siglo IV a.C., con un hiatus durante los tres primeros tercios del siglo V a.C. A la primera mitad del siglo IV se adscriben fragmentos de crateras de campana, copas del grupo de Viena 116, copas-escifos y una gama importante de cerámica de barniz negro (García Huerta y Morales Hervás, 1999: 337).

J. Hurtado cita varios yacimientos de esta provincia de Ciudad Real con importaciones de cerámica de figuras rojas como el Cerro de las Nieves, Los Toriles o Motilla de las Cañas que han aportado en el curso de su excavación diversos fragmentos de cerámica griega, siendo las formas más representadas los escifos y las cilicas de figuras rojas fechadas a finales del siglo $\mathrm{V} y$ durante todo el siglo IV a.C. Es posible que la ciudad de Cástulo, en el Alto Guadalquivir fuera en este periodo un importante centro distribuidor de las cerámicas griegas de esta región (Hurtado, 2001: 71-86)

Un aspecto que resaltan García Huerta y Morales Hervás es el hecho de que en esta provincia prácticamente todos los restos de cerámica griega proceden de poblados, frente al alto porcentaje de cerámica griega documentada, en otros puntos de la Península Ibérica, en contextos funerarios, motivo, que, como los propios investigadores señalan, podría deberse al escaso conocimiento de las necrópolis.

Provincias de Toledo y Madrid. En estas dos provincias también se han documentado cerámicas de barniz rojo. Para Toledo, Hurtado cita el Cerrón de Illescas y Yeles; para Madrid señala Cerro Redondo (Fuente del Saz, Jarama). La presencia de esta cerámica es un claro exponente de los influjos ibéricos en la submeseta sur, su presencia en la región carpetana puede deberse a intercambios comerciales con otras zonas de la península (Hurtado, 2001: 71-86).

Cargamento del barco del Sec (Calviá, Mallorca): Las cincuenta y tres piezas trasportadas por la nave presentan una gran uniformidad, lo que hace suponer que pertenecen a una misma hornada (Arribas, Trias et alii, 1987). 
La frecuencia de este tipo de copa en el mundo ibérico del sur y sureste peninsular no tiene paralelo con ninguna otra área del Mediterráneo; fueron los vasos griegos más frecuentes en todos lo tiempos del ámbito peninsular. La concentración de este tipo de copas, muy numerosas -como ya hemos señalado líneas arriba- en toda la mitad sureste de la Península así como en Andalucía, parecen indicar que éstos, junto a cráteras de campana, cantaros, copas y cuencos, páteras, bolsales y escifos, eran elegidos, deliberadamente, por la elite para que formaran parte de su mobiliario funerario

\section{INTERPRETACIÓN POR LA SOCIEDAD INDÍ- GENA.}

La doctora C. Sánchez, gran especialista en cerámica griega -como hemos tenido ocasión de comprobar a lo largo de éstas páginas-, considera que las series de imágenes conservadas en los vasos griegos reflejan, mejor que cualquier obra de arte, los cambios sociales, políticos y económicos de la comunidad ateniense. Se utilizaron en muchas de las actividades de la ciudad, en fiestas, juegos, banquetes, etc. Están presentes en los momentos decisivos de la vida, acompañan a los hombres y mujeres en el tránsito del matrimonio, como regalos de boda y en la muerte, los lecitos de fondo blanco -vasos que contienen perfumesson el ajuar funerario habitual en época clásica. Los vasos, por tanto, se conciben desde un principio con una función determinada: como contenedores de aceites perfumados, de vino, de agua, como vasos rituales, como vajilla de lujo, etc., y muchas veces el uso del vaso determinaba su iconografía (Sánchez, 1992: 23). Ya hemos visto como los artistas del Barrio del Cerámico de Atenas fabricaban vasos para la exportación y como estos vasos-mercancía llegaban a mercados helenizados, etruscos, y a lugares alejados y bárbaros donde habitaban tracios, escitas o iberos. La citada investigadora señala que pudo haber existido una posible adaptación de la iconografía al gusto del comprador: los vasos destinados al mercado tracio se decoraban con figuras vestidas a la moda tracia o con temas como el de Orfeo tocando la lira ante sus compatriotas; al Mar Negro se enviaban los vasos con gigantomaquias, amazonomaquias o peleas entre grullas y pigmeos. En el caso de la Península Ibérica, los griegos tuvieron una visión del lejano occidente mucho más imprecisa y desdibujada que la que tenían de otras zonas periféricas de su mundo. No hay en la cerámica griega representaciones de tipos iberos, como existen de tracios, escitas o frigios, ni tampoco temas iconográficos exportados a la Península que puedan considerarse como occidentales (Sánchez, 1992: 24).

En Grecia la crátera se utilizaba para la mezcla del vino y del agua y la cilica o copa de dos asas para beber. Era una copa colectiva, se pasaba de mano en mano, entre los comensales que asistían al banquete, junto con las bromas, los versos o los requiebros amorosos. En el mundo ibérico, el vaso griego colectivo se transforma en vaso individual ya que éste individualizaba a su rico poseedor del resto de los de su condición social y de la sociedad que no tenía acceso a estos lujosos y hermosos vasos. La crátera se utilizará, sobre todo, para depositar las cenizas de los difuntos y por ello se harán cada vez de menor tamaño. Con esta reducción aumentó la ganacia de los intermediarios (Olmos y Sánchez, 1995: 111, 124 y 125). Vemos por tanto, como estos vasos áticos, a su llegada a la Península ven transformado su uso y este no suele coincidir con la función para la que fue concebido. El uso griego tiene para el indígena el valor de un objeto precioso y pierde, en el momento en que se produce el intercambio comercial, su estatus original como pieza de vajilla. Aunque la mayoría de los contextos son funerarios, como ya se ha indicado, las piezas griegas también se documentan en los poblados. Las lañas, las reparaciones de algunas de ellas halladas en tumbas, indican una reutilización funeraria tras, probablemente, un uso cotidiano. En los contextos funerarios los vasos griegos abiertos se utilizan como los platos y cuencos ibéricos, es decir, conteniendo ofrendas o como tapaderas de urnas cinerarias y los grandes vasos como contenedores de las cenizas de los muertos (Sánchez, 2000: 179-193 y Olmos y Sánchez, 1995: 107136).

La citada investigadora también señala que el gusto del comprador indígena por vasos bien articulados, con dos asas, se pone de manifiesto en el siglo $\mathrm{V}$ a.C., cuando ya son muy frecuentes las copas de tipo Cástulo.

Para R. Olmos, las decoraciones de las copas del Grupo de Viena 116 que podemos encontrar en la Península, no tendrían un carácter irrelevante; considera que pudo haber existido una mediación y una reinterpretación púnica de los motivos formales griegos. Cree que los comer- 
ciantes púnicos pudieron elegir las copas decoradas con unos motivos concretos porque en ellos quisieron reconocer algunas representaciones de sus divinidades, por ejemplo, en la imagen del ánodos de una diosa sola o en presencia de un adorante pudo reconocerse la imagen de Tánit. Según afirma el investigador citado anteriormente, para los iberos, estas imágenes llegaron a poseer un nuevo contenido simbólico: la epifanía de la diosa infernal, quienquiera que esta sea (Afrodita, Perséfone o Tánit), en definitiva una diosa de la tierra o del más allá (Olmos,1988: 315-318)

Las copas áticas decoradas en el interior con escenas de palestra -jóvenes atletas acompañados por elementos característicos del gimnasio, como discos o aríbalos- y en el exterior con jóvenes ataviados con himatión afrontados presentan imágenes muy degeneradas, repetidas con mínimas variantes y halladas a cientos en la Península. La pregunta que se hace la mayoría de los investigadores es si los iberos eligieron la iconografía deliberadamente o si ésta era secundaria y lo que importaba era el soporte, es decir, en este caso la copa. El Dr. Olmos, considera que las escenas representadas serían - probablemente- ilegibles para el ibero, que adquiere estos vasos imitando una moda y buscando posiblemente, con su posesión, un símbolo de prestigio (Olmos, 1992: 7879). Para C. Sánchez, los iberos pudieron identificarse con los jóvenes envueltos en mantos y cree que podría existir, en el pensamiento ibérico, la idea de una heroización a través del vestido o quizá la diferenciación por el manto de determinadas clases sociales.

En relación a las copas decoradas con cabeza femenina en el medallón interior, que surge del suelo -ánodos-, se han interpretado por C. Sánchez como la representación de la diosa que brota del suelo. En la sociedad griega tuvo un carácter funerario y éste mismo pudo tener para el ibero que se enterraba con ella.

En definitiva, sería posible que las imágenes representadas en estas copas fueran leídas o reconocidas por el ibero que se enterraba con ellas (Sánchez, 1994: 206).

\section{EL CONTEXTO ARQUELÓGICO}

Como ya hemos dejado claro líneas arriba, el fragmento cerámico aquí estudiado fue documentado en la fase celtibérica del yacimiento excava- do en El Cerro de Alvar-Fañez, un oppidum ólcade, tal vez la Istonium citada por las fuentes literarias, concretamente por Tolomeo es sus Graduaciones o Tablas Geográficas.

En relación al pueblo celtibérico de los ólcades son pocas las alusiones que a ellos se hacen en las fuentes literarias, éstas se limitan a los pasajes sobre las campañas que Anibal realizó en la península ibérica entre el 219 y 211 a.C. La ausencia de otras menciones con posterioridad a estas fechas da lugar, como ha señalado Burillo Mozota, a la aceptación de que esta etnia y el territorio que le correspondería quedaran englobadas más tarde en alguna otra de las que conocemos. Tanto Polibio como Tito Livio y Esteban de Bizancio coinciden en resaltar la importancia de una ciudad, que sería el centro de los ólcades, aunque los autores no se ponen de acuerdo en cúanto a su nombre. Polibio la llama Althea y dice de ella: "Anibal, tomando el mando, se puso al instante en marcha para sujetar a los ólcades; llegó delante de Althea, su ciudad más fuerte, acampó, y después de vigorosos y terribles ataques se apoderó rápidamente de ella. Los restantes pueblos, aterrados por este hecho, se entregaron a los cartagineses. Impuso una contribución a estas ciudades y dueño de grandes riquezas marchó a invernar a Cartagena (Polibio, $3,13,5)$. En relación al año 218 a.c. Polibio $(3,33,7)$ señala que "eran los que pasaron a África (en el ejército de Anibal), los tersitas, martianos, oretes, iberos y ólcades". Tito Livio llama a la principal ciudad ólcade, Cartala y en relación a ella señala : "(Anibal)... llevó primero el ejército hacia el territorio de los ólcades, pueblo situado al otro lado del Ebro y que más que estar sometidos a Cartago figuraban entre sus amigos" “... toma y soquea Cartala, su capital, ciudad opulenta, por lo cual aterrorizadas las ciudades menores se sometieron y aceptaron el tributo" (Tito Livio, XXI,5,2). Esteban de Bizancio, fuente tardía basada en Polibio señala con respecto al centro de mayor importancia "Althaia, ciudad de los ólcades, los otros ólcades etnos de Iberia, vecinos de Cartago".

F. Burillo señala respecto a la doble denominación que Schulten había planteado que tal vez pudiera corresponder a dos tradiciones diferentes: la cartaginesa; y por tanto que Tito Livio tomara la raíz Cart- ; y la griega que habría inspirado a Polibio. Althaia significa en griego malvavisco, por lo que es posible que se tratara de la traducción griega de un nombre indígena. 
Debido, pues, a estas escasas alusiones literarias, para el Profesor Burillo se carecería de criterios seguros para la ubicación de los ólcades ya que la única posición geográfica que se ofrece por Tito Livio es muy vaga: al sur del Ebro. A partir de los acontecimientos que se cuentan entre el 221 y 229 a.C. y en los que se involucra, se puede deducir una vecindad con los carpetanos, la parte meridional del territorio vacceo y el río Tajo. Su ubicación en el territorio conquense es el ámbito que le han dado varios investigadores, entre ellos Martín Almagro y es el comúnmente aceptado (Burillo, 2007:188-192).

Volviendo al yacimiento del Cerro de Alvar Fañez y a su identificación con la Istonium de Tolomeo, ésta ya fue realizada por Miguel Cortés y López (1836) en su Diccionario Geográfico de la España Antigua Tarraconense, Betica, donde se dice que Istonium significa: hito, arrojamiento o señal divisoria, significado que concuerda bien con el enclave del yacimiento de Alvar-Fañez, una división natural entre las vegas del río Mayor y Aldehuela. En relación a Istonium, Miguel Cortés recoge lo siguiente: "Sabemos de positivo acerca de esta ciudad que estaba en la Celtiberia rigurosa, y que era de las más occidentales de esta región tocando ya con la Carpetania. Comparada su altitud con la de Valeria, estaba Istonium veinticinco minutos más alta de occidente de esta ciudad, no mencionada por otro" “... El fabuloso P. Higuera soñó que había estado en Villavieja, despoblado cercano a Hito" “.. según Cornide en su memoria. Tom.3 de las de la Academia, mudó de pensar Higuera, y creyó hallar a Istonium enterrada en La Redonda, o en Los Fosos de Bayona. Antes u otra vez la redujo a Cañavete, y esto le pareció mejor al citado Cornide. Jacome Capistrano de Maya opinó primero que Istonium había en Villavieja, despoblado junto al río Xiguela. Más pasados algunos años, cuando el $\mathrm{P}$. Risco dijo que era evidente el sitio de Certima en Alconchel, y que Munda estaba distante de Certima XX millas, fundando su demostración en dos inscripciones, calificadas ya mucho antes de apócrifas por D. Gregorio Mayans. Capistrano arrancó de Villasviejas a su Istonium y colocó allí a Munda. Si se hubiera de juzgar solamente por alguna, aunque remota, analogía parecería verosimil que Istonium hubiera estado en Hito, y así han opinado algunos; pero Hito ni está a la latitud que Tolomeo dió a Istonium, estando en el mismo paralelo que Valería, y no veinticinco o seis leguas, como lo estaba Istonium; ni hay necesidad de buscar la remota semejanza de Hito, teniendole idéntico, evidente y elevada en la ciudad de Huete. Esta es sin disputa la antigua Istonium; todos la tenían delante de los ojos y nadie hacia alto de ella, de su antigüedad, de su latitud al norte de Valeria, de su longitud arrimada ya a la Carpetania, y sobre todo de su nombre. La falta de observación sobre las alteraciones que causan con los nombres las pronunciaciones o dialectos, ha sido la causa de que ningún escritor haya fijado a Istonium en Huete. Pronunciado Istonium a lo eólico, muy usado modo de pronunciar en los latinos se convirtió en Vistonium o Histonium, luego en Vette y Huedde o Vedde: así era llamada en tiempo de los árabes; y últimamente en Huete..." “... Ruy Vamba opinó que Istonium estuvo en Cabeza de Griego, sin que este escritor, ni Risco, ni a Masden hayan hecho fuerza los argumentos con que se ha querido probar haber estado allí la antigua Segobriga".

Istonium, al igual que el resto de oppida ólcades (Althea, Cartala, Segobriga, Caesada, Valeria o Ercávica) situadas en las altiplanices del occidente de Cuenca, presenta una posición estratégica sobre el valle conformado entre el río Mayor y el rio Aldehula, y tuvo una excelente visibilidad sobre los terrenos adyacentes, circunstancia que explica, en gran medida, el hecho de que se trate de un enclave con continuidad poblacional desde el Hierro II o época tardorromana.

De esta fase celtibérica no hemos encontrado estructuras arquitectónicas, aunque si contamos con abundantes elementos de cultura material: cerámicas de barniz negro (IV a.C.); cerámica pintada ibérica; monedas acuñadas en las cecas de Arse (sagunto); Bilbilis (Calatayud); Titiakos (Tricio) y Sekaisa (Belmente de Gracina), con cronologías que no van más allá del 133 a.C., así como fíbulas anulares hispánicas. Todo ello evidencia la ocupación del espacio del yacimiento por parte de una comunidad que establecía diferentes ámbitos (atlántico y mediterráno) en los momentos previos y durante la fase de conquista romana.

Las siguientes fases de ocupación corresponden a época republicana y comienzos del imperio, momento en que el yacimiento alcanza su mayor importancia, importancia que pudo venir determinada por la explotación de las minas de lapis specularis, minería que se gestionó como una minería de interior. Su explotación modeló el paisaje y dinamizó la región. Las elites locales y 
las ciudades cercanas, entre ellas, Istonium u Opta fueron las más beneficiadas (Bermúdez Gómez y Guisado di Monti, 2004: 253).

La ciudad romana del Cerro de Alvar- Fañez pudo haber funcionado como un centro gestor de la explotación del lapis, explotación que estaría bajo el control de Segobriga. Esta ciudad fue el epicentro geográfico del conjunto minero extendido por las zonas de Sierra, Alcarria y Mancha de la provincia de Cuenca (Guisado di Monti y Bermúdez Gómez, 2002: 277-278).

La última fase de cierta vitalidad en el yacimiento corresponde con el Bajo Imperio. El declive de Istonium/Opta, a partir de esta época podría explicarse por el uso del vidrio soplado que se impuso finalmente sobre el empleo del lapis specularis para la construcción de ventanales. Esta nueva moda trajo consigo el abandono de las minas de yeso ubicadas en su entorno y esta circunstancia acabó con la razón de existir de este enclave (Castelo et alii, 2004:118).

La secuencia del poblamiento constatada en Alvar-Fañez reviste un gran interés, ya que a través de ella es posible estudiar los fenómenos de evolución, cambio y continuidad que registran las sociedades protohistóricas en el proceso de romanización.

En definitiva, la ciudad, primaro celtibérica y después romana situada en El Cerro de Alvar-Fañez se presenta, a tenor de los estudios arqueológicos como uno de los yacimientos más especialmente significativos, en relación con las grandes ciudades romanas de Segobriga, Ercavica y Valeria, jugando un papel de centro económico relevante en las fases republicana y altoimperial. En segundo lugar porque se muestra un espacio de evolución cultural en el que quedan de manifiesto los importantes procesos de aculturación a que se vieron sometidos los habitantes de la meseta con la llegada de los conquistadores romanos.

\section{Bibliografía.}

ALMAGRO GORBEA, M. (2005): "Segobriga (Saelices, Cuenca)", Celtiberos tras la estela de Numancia, 191-196.

ARRIBAS, A.; TRIAS, G. et alii (1987): El barco de El Sec (Costa de Calviá, Mallorca). Estudio de materiales, Mallorca.
BERNÁRDEZ GÓMEZ, M.J. Y GUISADO DI MONTI, J.C. (2004): “ La minería romana del lapis specularis. Una minería de interior", Investigaciones arqueológicas en Castilla-La Mancha 1996-2001, pp. 245-256.

BLANCO FREIJEIRO, A. (1959): “Cerámica griega de los Castellones de Ceal", Archivo Español de Arqueología, XXXII, no 99 y 100, 106 y ss., Madrid.

BLÁNQUEZ, J. (1995): "La necrópolis tumular ibérica de El Salobral (Albacete)", Verdolay, 7. 199208, Murcia.

BURILLO MOZOTA, F. (2007): Los celtiberos. Etnias y Estados.

CABRERA BONET, P. (1987): “Consideraciones en torno a la cerámica ática de fines del siglo $\mathrm{V}$ en Extremadura", Oretum, III, 217-221.

CABRERA BONET, P. (1994): "Cádiz y el comercio de productos griegos en Andalucía occidental", Trabajos de Prehistoria, 51, vol. 2, 89-101, Madrid.

CABRERA BONET, P. (1995): “ La comercialización del vino griego en la Hispania prerromana", Arqueología del vino. Los orígenes del vino en occidente, 139-156, Jerez de la Frontera.

CABRERA BONET, P. (1997): "La presencia griega en Andalucía (ss. VI-IV a.C.)", en Fernández Jurado et alii (ed). La Andalucía ibero-turdetana (s. VI-IV a.C.), Actas de las Jornadas celebradas en el Foro Iberoamericano de La Rábida (Palos de la Frontera, Huelva), 369-390, Huelva.

CABRERA, P Y ROUILLARD, P. (2004): “El pecio de El Sec en la Bahía de Palma de Mallorca (mediados del s. IV)", El vaso griego y sus destinos, pp. 125-131, Madrid.

CABRERA, P Y ROUILLARD, P. (2004): “El grupo de Telos. Pintores atenienses de mediados del siglo IV a.C.", El vaso griego y sus destinos, pp. 91-98, Madrid.

CABRERA, P. Y SÁNCHEZ, C. (2000): "El comercio griego con el mundo ibérico durante la época clásica”, Los griegos en España. Tras las huellas de Heracles, 133-144, Madrid.

CALVO PÉREZ, B.(s.a) El Museo Histórico Minero Don Felipe de Borbón y Grecia.

CASTELO, R. ET ALII (2000) “Arqueología en la comarca de la Alcarria Conquense. Avance de las investigaciones sobre el yacimiento de El Cerro 
de Alvar-Fañez (Huete, Cuenca)", Cuadernos de Prehistoria y Arqueología UAM, 26, pp. 95-149.

CATÁLOGO LOS GRIEGOS EN ESPAÑA. TRAS LAS HUELLAS DE HERACLES, 2000, Madrid.

CORTÉS Y LÓPEZ, M. (1836): Diccionario geográfico de la España Antigua, Tarraconense, Betica.

CUADRADO, E. (1987): La necrópolis ibérica de El Cigarralejo (Mula, Murcia).

FERNÁNDEZ OCHOA, C. et alii (1994): Sisapo I. Excavaciones arqueológicas en la Bienvenida, Almodovar del Campo (Ciudad Real), Albacete.

GARCIA CANO, C. (1997): "El departamento B de la Loma del Escorial (Los Nietos, Cartagena)", Verdolay, 7, 259-269, Murcia.

GARCÍA CANO, J.M. (1982): Cerámicas griegas en la región de Murcia, Murcia.

GARCÍA CANO, J.M. (1995): "El territorio oriental de la meseta y el sureste peninsular", El mundo ibérico: una nueva imagen en los albores del año 2000, 127-131, Albacete.

GARCÍA CANO, J.M. (1998): "La cerámica ática”, Museo de El Cigarralejo (Mula, Murcia). Boletín de la Asociación Española de Amigos de la Arqueología, 38, 161-174, Madrid.

GARCÍA CANO, J.M. (2205): "El comercio en base a la necrópolis", El Museo de Arte ibérico El Cigarralejo de Mula. Exposición permanente, 77-86, Murcia.

GARCÍA CANO, J.M. Y PAGE DEL POZO, V. (1994): "Panorama actual de las cerámicas griegas en Murcia (1982-1991)", Iberos y Griegos: lecturas desde la diversidad, Simposium Internacional de Ampurias, 217-239 (Ampurias, 1991).

GARCÍA CANO, J.M. Y PAGE DEL POZO, V. (2001): "El armamento de la necrópolis de Castillejo de Los Baños. Una aproximación a la panoplia ibérica de Fortuna (Murcia)", Gladius, XXI, 57-136.

GARCÍA CANO, J.M. Y PAGE DEL POZO, V. (2007): 30 Años de investigación en Coimbra del Barranco Ancho. Jumilla, Murcia.

GARCÍA HUERTA, R. (1995): "Ritos funerarios y muerte en la cultura ibérica”, El mundo ibérico: una nueva imagen en los albores del año 2000, 65-103, Albacete.
GARCÍA HUERTA, R y MORALES HERVÁS, J. (1995): "La cerámica griega en la provincia de Ciudad Real", XXI Congreso Nacional de Arqueología, vol. I, 117-125, Zaragoza.

GARCÍA HUERTA, R y MORALES HERVÁS, J. (1999): “ La cerámica griega en la meseta sudoocidental", II Congreso de Arqueología peninsular, Tomo III: Primer milenio y metodología, 335-345, Alcalá de Henares.

GARCÍA I MARTÍN, J.M. (1996): “ Les cerámiques átiques del Tossal de Manises (Alacant, L'Alacanti). Els fons antics del Museo Arqueológic Provincial d' Alacant", Actas del XXIII Congreso Nacional de Arqueología, 467472.

GARCÍA I MARTÍN, J.M. (1997): en Olcina Domenech, M. (ed.): "Les cerámiques grecques. La llleta dels Banyets (El Campello, Alicante)", Estudios de la Edad del Bronce y época Ibérica.

GRAU MIRA, I. (2000): "Territorio y lugares de culto en el área central de la Contestania Ibérica", Cuadernos de Prehistoria y Arqueología Castellonense, 21, pp. 195-226).

HURTADO AGUÑA, J. (2001): "La economía del área carpetana en época republicana y altomedieval", Iberia. Revista de la Antigüedad, 71-86.

JIMÉNEZ ÁVILA, J. Y ORTEGA BLANCO, J. (2006): "El comercio griego en Extremadura (ss. VI-IV a.C.)", Revista de Estudios Extremeños. Vol.62, n ${ }^{\circ} 1,105-140$.

MOLINOS MOLINOS, M. ET ALII (1998): El santuario heróico de El Pajarillo (Huelma, Jaén)

MORET, P. et alii (1996): "La Pícola (Santa Pola): un asentamiento fortificado de los siglos V y IV a.C. en el litoral costero alicantino", Actas del XXIII Congreso Nacional de Arqueología, Vol. I, 401406, Alicante (Elche, 1995).

OLMOS, R. (1988): “Anotaciones iconográficas a las copas del siglo IV a.C. de Cástulo: conjeturas púnicas”, en García Gelabert, Mª.P. y Blázquez, J.M : Cástulo, Jaén, España. I. Excavaciones en la necrópolis ibérica del Estacar de Robarinas (s.IV a.C.,) BAR International Series 425, 315323.

OLMOS, R. Y SÁNCHEZ, C. (1995): "Usos e ideología del vino en las imágenes de la Hispania prerromana", Arqueología del vino. Los orígenes del vino en occidente, 139-156, Jerez de la Frontera. 
PATIÑO GÓMEZ, M.J. (1995): "Estado actual de la investigación sobre la cerámica griega en Castilla-La Mancha”, Actas del Primer Congreso de Historia de Castilla-La Mancha, 301-326.

PICAZO, M. (1977): Cerámicas áticas de Ullastret.

PRESESO VELO, J. (1982): La necrópolis de Baza, E.Arq.E., 119, Madrid.

ROUILLARD, P. (1975): "Les coupes attiques a figures rouges du IV s. en Andalousie", Melanges de la casa de Velázquez, IX, 21-49, Paris.

ROUILLARD, P. (1993): "Le vase grec á Cabezo Lucero", La nécropole ibérique de Cabezo Lucero, Guardamar del Segura, Alicante.

SALA SELLÉS, F Y HERNÁNDEZ ALCARAZ, L. (1998) "La necrópolis de El Puntal (Salinas, Alicante): aspectos funerarios ibéricos del siglo IV a.C. en el Corredor del Vinalopó", Cuadernos de Prehistoria y Arqueología castellonense, 19.

SÁNCHEZ, C. (1988): "Cerámica ática de la necrópolis de Estacar de Robarinas", en García Gelabert. $\mathrm{M}^{\mathrm{a}}$.P. y Blázquez, J.M ${ }^{\mathrm{a}}$ : Cástulo, Jaén, España. I. Excavaciones en la necrópolis ibérica del Estacar de Robarinas (s.IV a.C.), BAR Internacional Series 425, 276-311.

SÁNCHEZ, C. (1992): “Imágenes de Atenas en el mundo ibérico. Análisis iconográfico de la cerámica ática del siglo IV a.C. hallada en Andalucía Oriental", Anuario del Departamento de Historia y Teoría del Arte, vol. VI, 23-33, Madrid.
SÁNCHEZ, C. (1994): "El comercio de vasos áticos en Andalucía Oriental en el siglo IV a.C. El Taller del Pintor del Tirso Negro", Iberos y Griegos: lecturas desde la diversidad, Simposium Internacional, 201-216 (Ampurias, 1991).

SÁNCHEZ, C. (1996): "Códigos de lectura en iconografía griega hallada en la Península Ibérica”, $A l$ otro lado del Espejo. Aproximación a la imagen ibérica, 73-84, Madrid.

SÁNCHEZ, C. (1998): "La cerámica ática de Castellones de Ceal hallada en las excavaciones dirigidas por C. Fernández Chicarro", en Chapa, T. et alii: La necrópolis ibérica de Los Castellones de Ceal (Hinojares, Jaén).

SÁNCHEZ, C. (2000): "Vasos griegos para los príncipes ibéricos”, Los griegos en España. Tras las huellas de Heracles, 179-193, Madrid.

VALENCIANO PRIETO, Mª C. (1998): "Llano de la Consolación. El renecer de una necrópolis olvidada”, Revista Arqueología, 212, 19-28.

VV.AA. (1993): "La interpretación de las imágenes importadas", La Sociedad ibérica a través de la imagen, Barcelona.

ZARZALEJOS, M. ET ALII (2004) "El proyecto Sisapo. La Bienvenida (Almodovar del Campo, Ciudad Real). Balance de los trabajos más recientes y nuevas perspectivas de la investigación”, Investigaciones arqueológicas en Castilla-La Mancha, 1996-2002, pp. 163-180. 